\title{
Pliocene integrated chronostratigraphy from the Anno Formation, Awa Group, Boso Peninsula, central Japan, and its paleoceanographic implications
}

\author{
Yuki Haneda ${ }^{1 *}$ (i) and Makoto Okada ${ }^{2}$
}

\begin{abstract}
The Pliocene climate is one of the best analogs for the climate of a globally warmer future. Here, we present a new Pliocene integrated chronostratigraphy from the Anno Formation in the uppermost Awa Group, which is distributed throughout the Boso Peninsula, central Japan, based on paleomagnetic and benthic foraminiferal oxygen isotope records. This new chronostratigraphy provides valuable constraints for paleoceanographic and paleoclimatic studies in the northwestern Pacific Ocean, where the number of paleoceanographic records is limited due to the lack of calcareous microfossils from deep-sea sediment cores, with the exception of some plateaus at water depths above the calcite compensation depth (CCD). Paleomagnetic results indicate that the Anno Formation corresponds to the period extending from the Nunivak normal polarity subchronozone (4.493-4.631 Ma) to Chron C2An.2n (3.116-3.207 Ma), which is just above the Mammoth reversed polarity subchronozone. Although foraminifera are not found in the middle Anno Formation, our oxygen isotope records from the upper and lower Anno Formation demonstrate the recording of glacial-interglacial cycles. However, the amplitude of our $\delta^{18} \mathrm{O}$ profile is much larger than that of the LRO4 stack, with similar to slightly lower glacial values and much lower interglacial values. This observation implies that the bottom water had lower $\delta^{18} \mathrm{O}$ values and/or a warmer water mass during interglacials compared with global average deep-water regions.
\end{abstract}

Keywords: Awa Group, Anno Formation, Oxygen isotope stratigraphy, Magnetostratigraphy, Pliocene

\section{Introduction}

During the Pliocene, Earth's climate was substantially warmer; it was characterized by limited variations in ice volume, global temperatures that were $\sim 2-3{ }^{\circ} \mathrm{C}$ higher relative to the present day, $\mathrm{CO}_{2}$ concentrations that were comparable to or higher than those today, suppressed Northern Hemisphere glaciation, and fully established East and West Antarctic Ice Sheets (Lisiecki and Raymo 2005; Naish et al. 2009; Lunt et al. 2010; Seki et al. 2010; Salzmann et al. 2011; De Schepper et al. 2014). Therefore, the Pliocene climate is one of the best analogs for a globally warmer future climate (Salzmann et al. 2011). However, Pliocene paleoceanographic records from the

\footnotetext{
* Correspondence: yuuki.haneda.paleo@gmail.com

${ }^{1}$ Graduate School of Science and Engineering, Ibaraki University, 2-1-1

Bunkyo, Mito, Ibaraki 310-8512, Japan

Full list of author information is available at the end of the article
}

northwestern Pacific Ocean are limited, which is attributable to the lack of calcareous microfossils from deep-sea sediment cores, with the exception of some plateaus at water depths above the Pacific calcite compensation depth (CCD).

The upper Awa Group is a middle Miocene-upper Pliocene marine deposit that is distributed throughout the Boso Peninsula and faces the North Pacific subarctic front between the Kuroshio and Oyashio Currents, which are wind-driven western boundary currents (Suzuki et al. 1995; Qiu 2001; Fig. 1a, b). In this deposit, calcareous nannofossils, foraminifera, radiolaria, and diatoms are well preserved (Oda 1977; Haga and Kotake 1996; Watanabe and Takahashi 2000; Kameo et al. 2002; Sawada et al. 2009; Kameo et al. 2010; Kameo and Sekine 2013), and widespread tephra beds are intercalated with these sediments (Kurokawa and Higuchi 

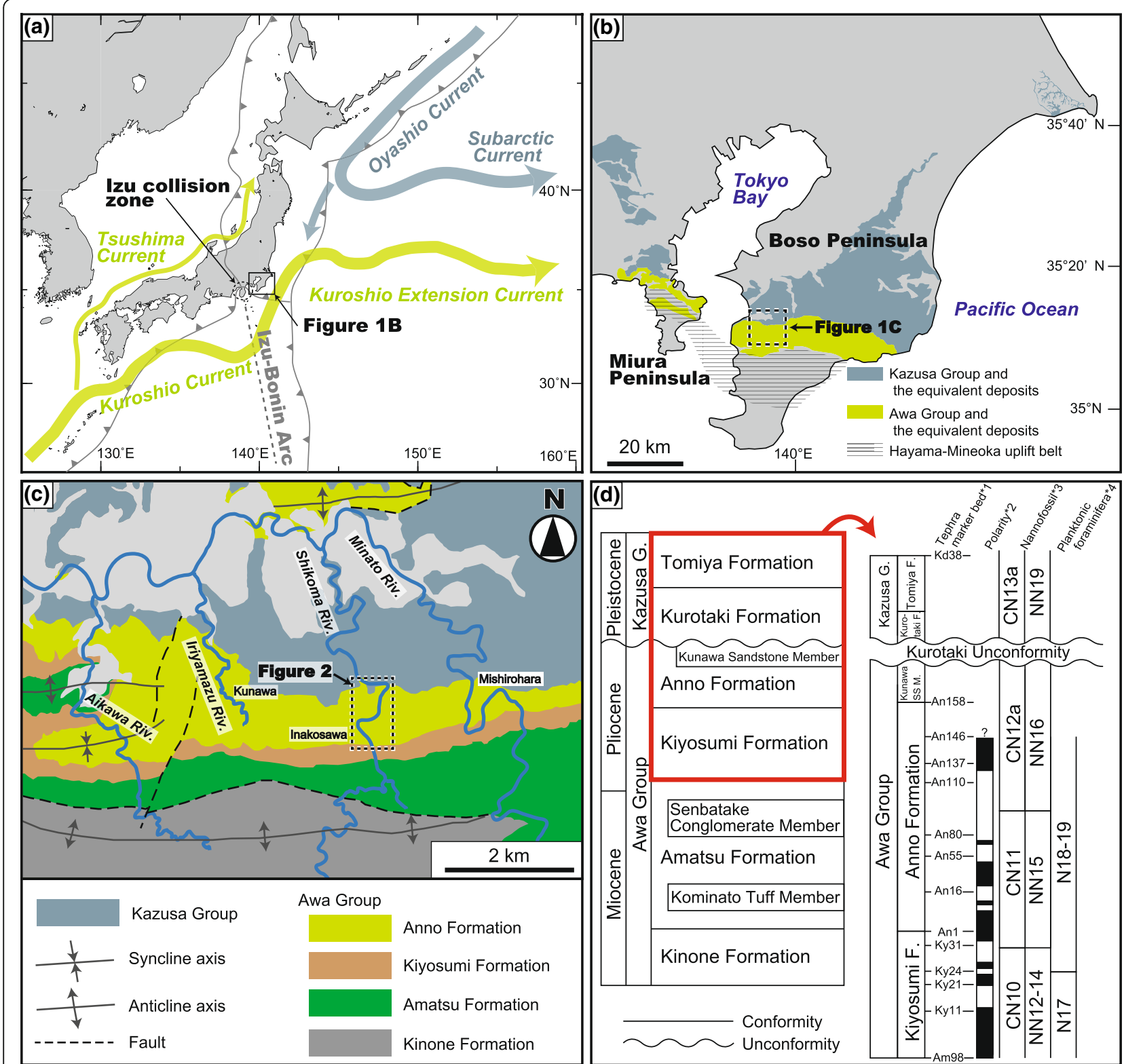

Fig. 1 Location map of the study site and stratigraphic summary of the Awa Group. a The Japanese archipelago with surface oceanography and tectonic setting. Surface oceanic currents are drawn after Qiu (2001). Tectonic setting is drawn after Tatsumi et al. (2016). b Distribution of the Awa and Kazusa Groups on the Boso and Miura Peninsulas based on Mitsunashi and Suda (1980), Unozawa et al. (1983), Sakamoto et al. (1987), and Takeuchi et al. (2015). c Distribution of the upper Awa Group. The Anno, Kiyosumi, Amatsu, and Kinone Formations in the Futtsu District are based on Nakajima and Watanabe (2005). The dashed box indicates the study area. $\mathbf{d}$ Typical stratigraphies of the upper Awa Group and lowermost Kazusa Group in the western Boso Peninsula are based on Nakajima and Watanabe (2005), and detailed stratigraphies are based on previous studies marked with asterisks. Calcareous nannofossil assemblage zonal schemes follow the CN and NN zonal code notations after Okada and Bukry (1980) and Martini (1971), respectively. Planktonic foraminiferal assemblage zonal schemes follow the N zonal code notation after Blow (1969). *1 Nakajima and Watanabe (2005), *2 Niitsuma (1976), *3 Kameo and Sekine (2013), and *4 Oda (1977)

2004; Satoguchi et al. 2005; Tamura et al. 2005; Tamura et al. 2008; Tamura and Yamazaki 2010; Satoguchi and Nagahashi 2012). Therefore, the Awa Group is known as a typical Neogene sequence in Japan, and it is suitable for reconstructing paleoceanographic environments during that period in the northwestern Pacific Ocean. However, no chronostratigraphy with a time resolution comparable to the span of glacial-interglacial cycles has yet been established. Here, we present a new Pliocene integrated chronostratigraphy based on new magnetostratigraphy and oxygen isotope stratigraphy results, which we constrain using existing calcareous nannofossil data and the radiometric dating results obtained from tephra beds in the Anno Formation of the uppermost 
Awa Group. We also discuss the paleoceanographic implications of the benthic foraminiferal oxygen isotope record.

\section{Geological setting}

The upper Awa Group is a middle Miocene-upper Pliocene forearc basin-fill deposit situated in the northern Hayama-Mineoka belt in the Boso Peninsula, which is located on the Pacific side of central Japan (Ito et al. 2016; Fig. 1a, b). The upper Awa Group consists of the Kinone, Amatsu, Kiyosumi, and Anno Formations, in ascending order, and it is unconformably overlain by the Kurotaki Formation above the Kurotaki Unconformity; this formation represents the lowermost Kazusa Group (Nakajima et al. 1981; Nakajima and Watanabe 2005; Fig. 1c, d). The erosion of the eastern Awa Group across this unconformity is larger than that in the western part. The resultant age gap in the western Boso Peninsula was inferred to be at least 1 million years based on the calcareous nannofossil biostratigraphy (Kameo and Sekine 2013). In contrast, the erosion reaches down to the Kiyosumi Formation in the eastern part of the peninsula, where the Anno Formation is completely missing (Tokuhashi and Iwawaki 1975).

The Anno Formation is a submarine fan deposit that settled within a submarine basin above the Kiyosumi Formation (Nakajima 1978; Tokuhashi 1988). It consists of the siltstone-dominated alternation of siltstones and sandstones with intercalated tephra beds. The siltstone becomes coarser toward the west, while the sandstone becomes thinner. In the westernmost Boso Peninsula, the Anno Formation consists of the alternation of sandy siltstones and tephra beds (Nakajima et al. 1981; Nakajima and Watanabe 2005). The uppermost Anno Formation, which has been named the Kunawa sandstone member, consists of sandstone and tuffaceous sandstone (Nakajima and Watanabe 2005). A total of 182 tephra marker beds labeled An1 through An182 are numbered, in ascending order, from the bottom to the top of the formation (Nakajima et al. 1981; Natural History Museum and Institute, Chiba 1993, 1995, 1996). Some tephra marker beds (An51, An53, An77, An85, An112, An129, and An130) are widely recognized throughout the Japanese Islands and are known as Trb1-Ya4, Sk-Ya5, Ksg-An77, Znp-Ohta, Ymp-SF8.3, Hgs-An129, and Sr-Ity, respectively (Kurokawa and Higuchi 2004; Satoguchi et al. 2005; Tamura et al. 2005, 2008; Tamura and Yamazaki 2010; Satoguchi and Nagahashi 2012). In particular, the Znp-Ohta and Sr-Ity tephra beds, which facilitate the comparison of Pliocene stratigraphies and paleoenvironmental records between the Japan Sea and the northwestern Pacific Ocean, have also been observed at the deep-sea sediment cores in the Japan Sea (Tada et al. 2018).
Previous chronostratigraphic studies of the Anno Formation Magnetostratigraphy (Niitsuma 1976), planktonic foraminiferal biostratigraphy (Oda 1977), calcareous nannofossil biostratigraphy (Kameo and Sekine 2013), and fission track dating (Tokuhashi et al. 2000) studies have been conducted on the Anno Formation (Fig. 1d). Niitsuma (1976) analyzed the remanent magnetization of sedimentary rocks from the upper Awa and Kazusa Groups using an astatic magnetometer and correlated the Anno Formation to the interval ranging from the upper Nunivak normal polarity subchronozone to the lower Gauss normal polarity chronozone. Meanwhile, Oda (1977) reported the planktonic foraminiferal assemblages of the Awa Group and correlated the lower-middle Anno Formation with the N18-N19 zones (Blow 1969). However, because these magneto-biostratigraphic studies were conducted before the current extensive tephra stratigraphic system was prepared, the stratigraphic correlations between bioevent horizons, polarity reversal horizons, and tephra marker beds have remained ambiguous. More recently, Kameo and Sekine (2013) correlated the Anno Formation with the calcareous nannofossil zones CN11-CN12a (Okada and Bukry 1980) and NN15-NN16 (Martini 1971), thereby facilitating the stratigraphic correlations between those bioevents and tephra marker beds.

Some radiometric ages have also been reported for tephra markers and widespread tephra beds that can be correlated with those in the Anno Formation. Tokuhashi et al. (2000) reported fission track ages for An49 $(3.9 \pm 0.4 \mathrm{Ma})$ and An73 $(3.7 \pm 0.2 \mathrm{Ma})$ following the $\zeta$-calibration (Hurford 1990a) of tephra marker beds from the lower Anno Formation. The Kosugaya volcanic ash bed in the Tokai Group (known as Ksg-An77) was dated to $4.0 \pm 0.5 \mathrm{Ma}$ using fission track dating (Makinouchi et al. 1983). Similarly, the Nakatsugawa I and II volcanic ash beds in the Tokai Group correlate to An85 (known as Znp-Ohta) and were dated to $3.97 \pm 0.39 \mathrm{Ma}$ and $3.94 \pm 0.07 \mathrm{Ma}$ using fission track and U-Pb dating methods, respectively (Ueki et al. 2018). These radiometric ages can help constrain the chronostratigraphy presented below.

\section{Methods/Experimental}

Field observations

We conducted lithological observations of the Anno Formation from the tephra marker bed of An1, which marks the base of the Anno Formation, to its upper limit at the Kurotaki Unconformity along the Shikoma River, where the Awa Group is well exposed (Fig. 1c). We constructed a $1 / 2500$ route map (Fig. 2) and a 1/50 lithologic column (Fig. 3), in which the tephra marker beds follow the reports of Nakajima et al. (1981), the Natural History Museum and Institute, Chiba (1993, 1995, 1996), and Nakajima and 


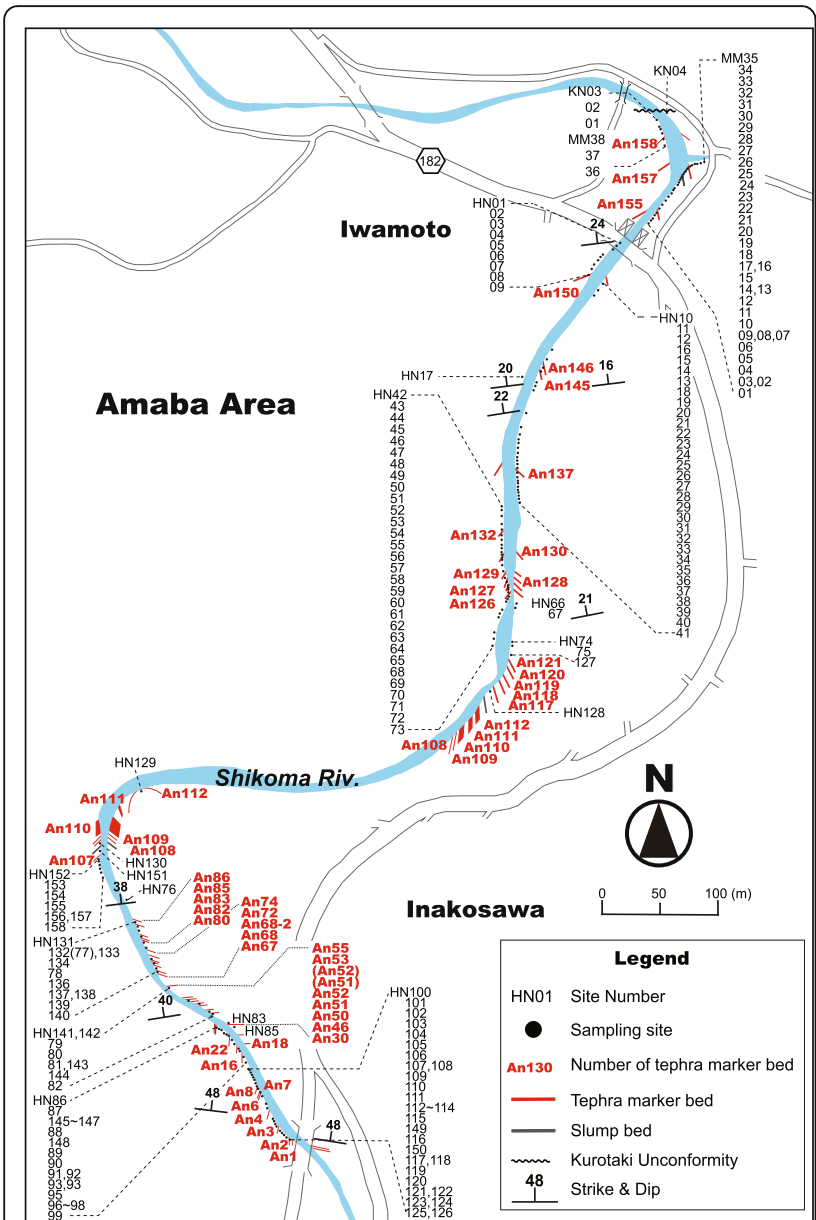

Fig. 2 Locations of tephra marker beds and sampling sites within the study area

Watanabe (2005), to develop a reliable stratigraphic framework of the studied sequence.

\section{Paleomagnetic and rock-magnetic measurements}

One to four drill cores (with 25-mm diameters) for rock-magnetic and paleomagnetic measurements were obtained at 200 horizons from siltstones or sandy siltstones (Figs. 2 and 3). These samples were collected using a portable drill and were oriented with a magnetic compass. Then, each paleomagnetic core was cut into a 2-cm-long specimen for paleomagnetic and rockmagnetic measurements at Ibaraki University.

The natural remanent magnetization (NRM) of each specimen was measured using a three-axis cryogenic magnetometer (SRM-760R; 2G Enterprises, USA) in a magnetically shielded room at the National Institute of Polar Research (NIPR) and the Center for Advanced Marine Core Research, Kochi University (KCC). To extract the primary magnetic component that indicates the geomagnetic field when a given geologic formation was formed, we conducted two demagnetization experiments to remove secondary components from the NRMs. Progressive alternating field demagnetization (pAFD) was performed in 5- to $10-\mathrm{mT}$ increments from 5 to $80 \mathrm{mT}$ using an AF demagnetizer with a set of static three-axis AF demagnetization coils installed on the magnetometer at the NIPR. Progressive thermal demagnetization (pThD) was performed at $50{ }^{\circ} \mathrm{C}$ increments from 100 to $600{ }^{\circ} \mathrm{C}$ using thermal demagnetizers (TDS-1; Natsuhara Giken, Japan) at the NIPR and KCC. Both progressive demagnetization techniques were performed on two selected specimens at each horizon.

Two experiments were conducted on selected specimens to identify the magnetic minerals in specimens. Thermomagnetic experiments were performed using a thermomagnetic balance (NMB-89; Natsuhara Giken, Japan) at the KCC. The specimens were heated to $700{ }^{\circ} \mathrm{C}$ and then cooled back to room temperature in a vacuum in an applied field of $0.3 \mathrm{~T}$. The J-T curves obtained by these experiments allow us to infer the magnetic minerals in specimens based on their Curie/Néel temperatures, blocking temperatures, and temperatures of thermal alteration. Low-temperature magnetic experiments were performed using a Magnetic Property Measurement System (XL5; Quantum Design, USA) at the KCC. The specimens were magnetized in a $1 \mathrm{~T}$ field and warmed to $300 \mathrm{~K}$ after cooling to $10 \mathrm{~K}$ in a zero-T field. Such experiments reveal the magnetic phase transition temperatures of the magnetic minerals included in a specimen without causing their alteration due to heating and/or oxidation.

Measurements of the magnetic hysteresis curve and first-order reversal curves (FORCs) were performed to infer the magnetic domain states of the magnetic particles within the studied specimens. The state of the magnetic domain is divided into a single domain (SD), a multi-domain (MD), and a magnetic vortex state, which has traditionally been termed the pseudo-single domain (PSD) (Roberts et al. 2017). The domain state depends on the grain size of the magnetic particles. The magnetic grains of the SD and/or vortex state (PSD), in which the grain size is much finer than that of the MD, play an important role in paleomagnetism because the magnetic stability is high enough to keep original magnetic signals throughout geologic time. Therefore, knowledge about the magnetic domain of magnetic particles within a studied sample is significant for validating paleomagnetic data. Magnetic hysteresis measurements were performed on selected specimens using an alternating gradient magnetometer (PMC MicroMag 2900 AGM; Lake Shore Cryogenics Inc., USA) at the NIPR with a maximum magnetic field of $0.5 \mathrm{~T}$. The Day diagrams (Day et al. 1977) was used to determine a broad distribution of the magnetic domain states of ferrimagnetic particles based on the saturation remanence to saturation magnetization $(M r s / M s)$ ratios and remanence coercivity to coercive 


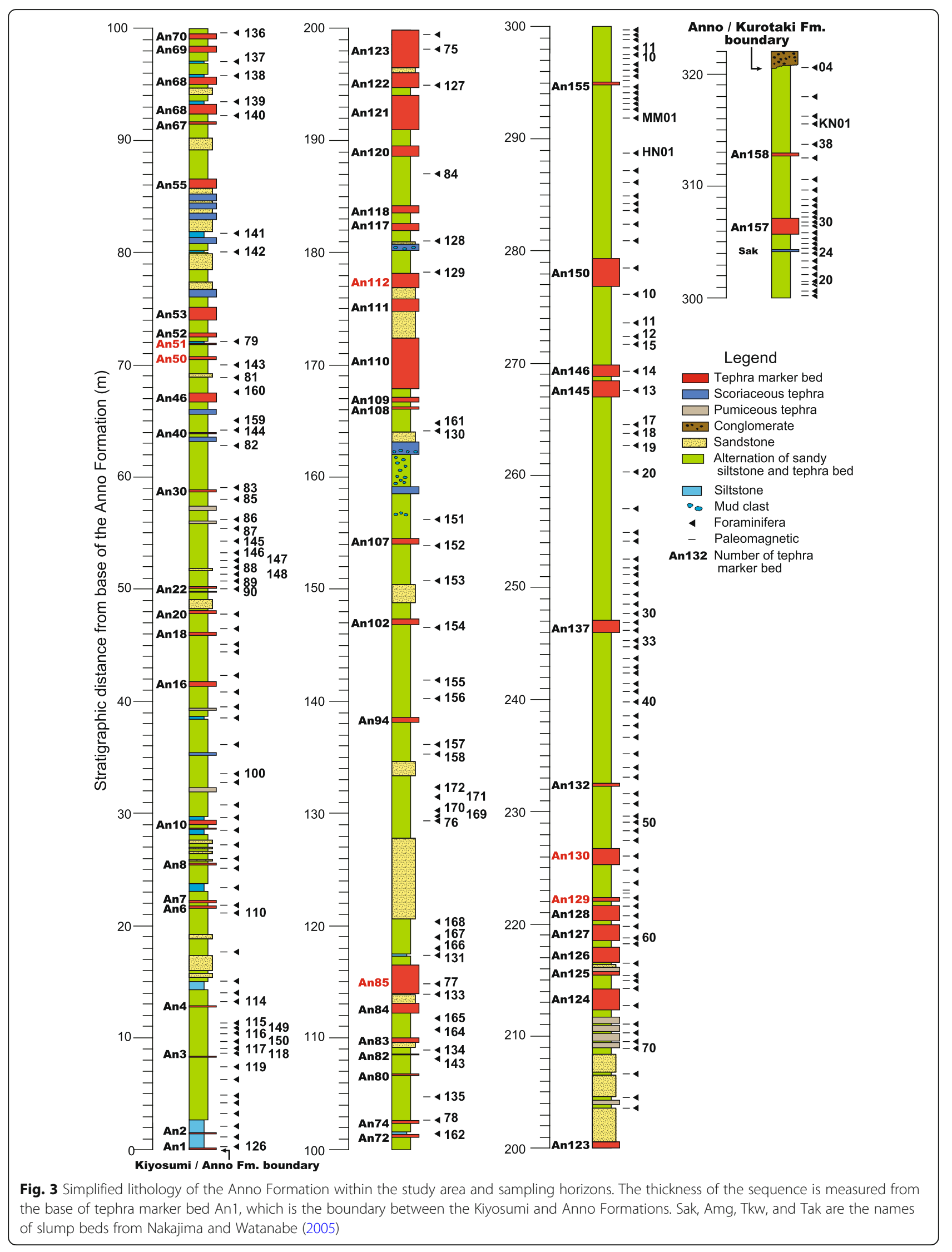


force $(\mathrm{Hcr} / \mathrm{Hc})$ ratios, which were observed from the magnetic hysteresis curves. FORC measurements were performed on selected samples using a vibrating sample magnetometer (PCM MicroMag 3900 VSM; Lake Shore Cryogenics Inc., USA) at the KCC. We measured 143 FORCs for each sample, with a field increment of $2 \mathrm{mT}$ and an average time of $150 \mathrm{~ms}$, in a $1 \mathrm{~T}$ saturating field. A FORC diagram represents a contour plot of the coercivity distribution of magnetic particles within a sample and their interaction field strengths (Pike et al. 1999; Roberts et al. 2000; Rowan and Roberts 2006). FORC distributions were calculated using a smoothing factor of 5 with the free FORCinel software (Harrison and Feinberg 2008).

\section{Oxygen isotope analysis}

Rock samples with dry weights of 300-400 g were obtained at the same horizons as paleomagnetic cores and in 10 horizons representing a total of 210 samples (Figs. 2 and 3). These samples were disaggregated using $\mathrm{Na}_{2} \mathrm{SO}_{4}$, and non-magnetic grains, including fossil foraminifera, were isolated from magnetic grains using a Frantz magnetic isodynamic separator. We manually picked benthic foraminiferal tests of Bolivinita quadrilatera, Melonis pompiloides, and Uvigerina spp. from the non-magnetic and $>100 \mu \mathrm{m}$ fractions of each sample. Selected foraminiferal tests were crashed and cleaned by ultrasonication in methanol for sample preparation. Oxygen isotope measurements were performed using a Finnigan-MAT 253 isotope ratio mass spectrometer with a Kiel IV carbonate device installed at the Department of Geology and Paleontology, National Museum of Nature and Science (NMNS) and a GV Instruments Ltd. IsoPrime stable isotope mass spectrometer with the Multicarb preparation system installed at the KCC. JCp-1, CO-1, and NBS-19 were used as analytical standards to calibrate the isotopic values to the Vienna Pee Dee Belemnite (VPDB). The analytical precision of the oxygen isotopes obtained from the replicated $\mathrm{CO}-1$ measurements at the $\mathrm{KCC}$ is $0.049 \%$, and that for the oxygen isotopes obtained from the replicated NBS-19 measurements at the NMNS is $0.038 \%$.

\section{Results and discussion}

\section{Rock-magnetic properties}

The results of the thermomagnetic and low-temperature magnetic analyses of the two selected specimens are shown in Fig. 4. The thermomagnetic experiments performed in vacuum demonstrate that the specimens have a single Curie/blocking temperature at approximately $570{ }^{\circ} \mathrm{C}$, without steep changes occurring throughout the heating and cooling processes, although the normalized induced magnetization $\left(J / J_{0}\right)$ through cooling is slightly larger than that through heating (Fig. 4a, b). These results indicate that the specimens contain (titano)magnetite with
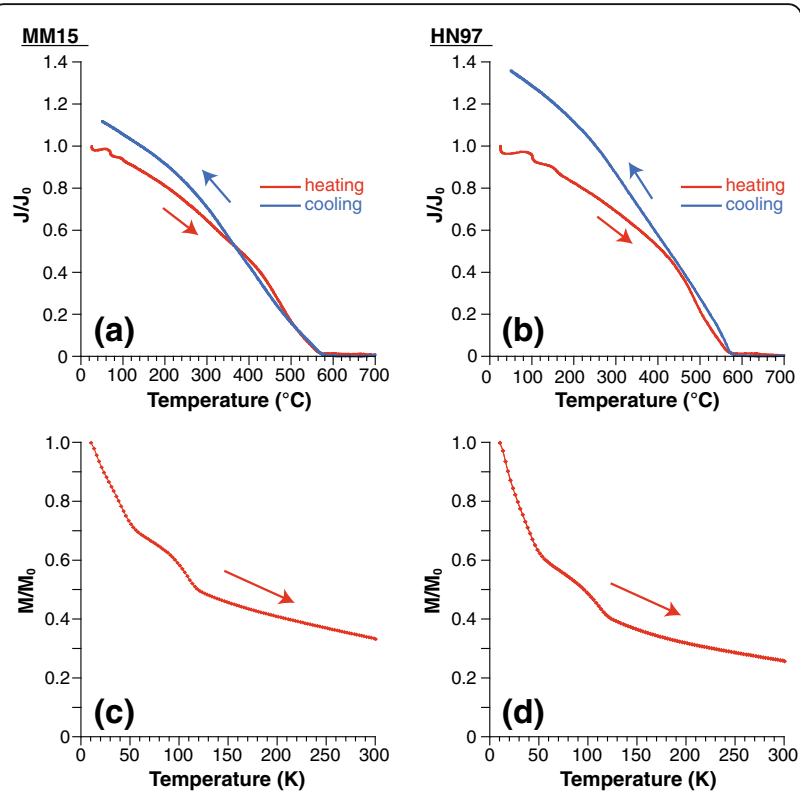

Fig. 4 Typical results of thermal magnetic and low-temperature magnetic experiments. Vertical axes indicate normalized values. a, b Results of thermal magnetic experiments in vacuum. Red and blue lines indicate induced magnetizations during heating and cooling, respectively. c, d Results of low-temperature magnetic experiments using specimens from the same horizons as (a) and (b), respectively

a Curie temperature close to that of magnetite at $585{ }^{\circ} \mathrm{C}$ (e.g., Hunt et al. 1995). The cooling curves are not reversible because of the degradation of iron oxyhydroxides within the specimens into ferrimagnetic minerals through heating or the minor thermal alteration of titanomagnetite (Bowles et al. 2013).

The low-temperature remanence curves (Fig. 4c, d) indicate the presence of a Verwey transition, where the magnetite transforms from a monoclinic to a cubic spinel structure between 110 and $120 \mathrm{~K}$ (Verwey 1939; Özdemir et al. 1993); the curves are characterized by a rapid remanence decline of $30-40 \%$ from 10 to $50 \mathrm{~K}$, with a broad Verwey transition from 100 to $120 \mathrm{~K}$. Özdemir et al. (1993) reported that the Verwey transition tends to shift to lower temperatures with a wider transition temperature range because of maghemitization (oxidation) occurring on the surface of magnetite. The rapid decrease in remanence occurring between 10 and $50 \mathrm{~K}$ is considered due to the influence of superparamagnetic particles (Özdemir et al. 1993; Özdemir and Dunlop 2010).

The Day diagram of selected specimens is shown in Fig. 5. The boundaries of the magnetic domain state regions for the Day diagram are indicated after Dunlop (2002). Almost all of the specimens fall into the vortex state (PSD) (Roberts et al. 2017) region, which can also be explained as mixtures of particles in the SD and MD states, although the data distribution is quite wide. 


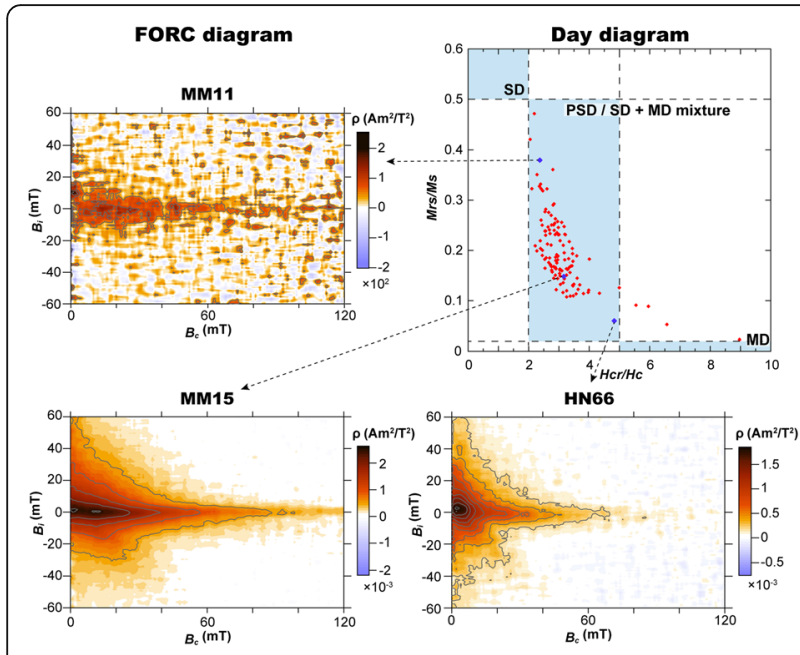

Fig. 5 Day diagram of hysteresis parameters and FORC diagrams for selected specimens. SD single domain, PSD pseudo-single domain, MD multi-domain; after Dunlop (2002)

The FORC diagrams in Fig. 5 show the distributions of the magnitudes of magnetic interaction $\left(B_{i}\right)$ and coercivity $\left(B_{c}\right)$ for three selected specimens whose data fall into a wide range of the vortex state (PSD) region in the Day diagram. In a FORC diagram, the vertical and horizontal axes provide the magnitudes of $B_{i}$ and $B_{c}$, respectively. For example, MD particle systems with weak domain wall pinning give rise to broad distributions along a vertical axis with low coercivities. In contrast, noninteracting uniaxial SD particle systems produce a sharp ridge-like horizontal distribution without a broad distribution along a vertical axis (Roberts et al. 2017, and references therein). In Fig. 5, MM11, which is close to the SD region, shows a horizontal ridge-like distribution by a coercivity of $\sim 90 \mathrm{mT}$ with a narrow distribution of $B_{i}$ between $\pm 20 \mathrm{mT}$, and it is similar to the FORC distributions obtained for SD particle systems (e.g., Pike et al. 1999; Roberts et al. 2000). HN66, which is close to the MD region, produces a broad distribution of $B_{i}$ between $\pm 60 \mathrm{mT}$ with a high coercivity of $\sim 60 \mathrm{mT}$. MM15, which falls into an intermediate vortex state (PSD) region in the Day diagram, shows a distribution as broad as that of HN66 along a vertical axis but a higher coercivity than HN66. These two FORC distributions are typical distributions of magnetic vortex state (PSD) particles (Roberts et al. 2017), although the distribution for HN66 seems to be reflected in a larger magnetic particle size. Therefore, the results of the rock-magnetic experiments indicate that the magnetic particles within the studied specimens generally consist of vortex state (titano)magnetite, which could acquire detrital remanent magnetization (DRM) as a primary magnetic signal.

\section{Remanent magnetization}

Typical orthogonal vector diagrams (Zijderveld 1967) for the NRMs obtained from pAFD and pThD are shown in Fig. 6. Most of the results from pAFD indicate that the NRMs consist of one or two characteristic remanent magnetizations (ChRMs). Secondary magnetization components were removed at a peak field of $15 \mathrm{mT}$, and the remanences demagnetize linearly toward the origin, but half of the intensity was removed by $10 \mathrm{mT}$ for some specimens (Fig. 6a). The demagnetization paths for the pThD results also consist of one or two components, with the secondary components demagnetized by 200 $300{ }^{\circ} \mathrm{C}$ (Fig. 6). The remanences were linearly demagnetized toward the origin by $600{ }^{\circ} \mathrm{C}$ without any curvilinear demagnetization paths. These results indicate that both methods provide almost identical demagnetization paths for each specimen (Fig. 6b-d), although the specimen in Fig. 6a had a pAFD path with a partly overlapping coercivity spectrum. The components linearly demagnetized toward the origin by $600{ }^{\circ} \mathrm{C}$ are carried by (titano)magnetite, which indicates that the primary magnetic signal is DRM.

In Fig. 6e, three components are evident, namely low$\left(0-150{ }^{\circ} \mathrm{C}\right)$, medium- $\left(200-350{ }^{\circ} \mathrm{C}\right)$, and hightemperature $\left(400-600{ }^{\circ} \mathrm{C}\right)$ components in the pThD result. In contrast, only one component shows a linear trend to the origin in the PAFD result, which has a direction similar to the low-temperature component in the pThD result. Specimens with different demagnetization patterns between pAFD and pThD, as shown in Fig. 6e, originate from horizons that record polarity transitions. This observation indicates that a low-temperature component of $\mathrm{pThD}$ resulting from a polarity transition is carried by a magnetically hard but low-Curie/Néel temperature mineral, such as goethite.

The geomagnetic field decays by approximately one order of magnitude during polarity transitions based on data sets derived from marine sediments (e.g., Valet et al. 2005) and lavas (e.g., Mochizuki et al. 2011). Sediment samples from transition zones tend to record the field, as there is no clear univectorial component attenuating to the origin, but as scattered data points because of the rapidity of geomagnetic changes in a weak field, which may generate multiple remanence components due to an acquisition mechanism of DRM (Valet and Fournier 2016). These studies suggest that a primary remanence recorded by a sedimentary rock during a polarity transition may be represented as a noisy component, and its intensity becomes much weaker than a secondary remanence recorded after the post-transitional recovery of the geomagnetic field.

From the Awa Group, Niitsuma (1976) observed goethite with a reflecting microscope in specimens with weak remanence and reported that thermal demagnetization at $200{ }^{\circ} \mathrm{C}$ was required to remove secondary remanence. These observations suggest that the secondary remanence 


\section{(a) $10.35 \mathrm{~m}$ HN116AA (AFD)

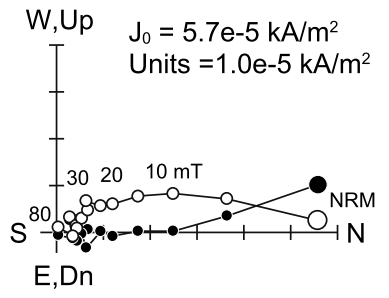

HN116AB (ThD)

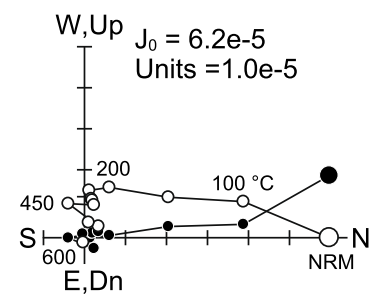

(b) $58.05 \mathrm{~m}$ HN85AA (AFD) HN85AB (ThD)

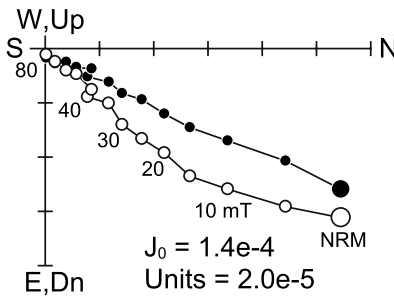

(c) $245.30 \mathrm{~m}$ HN33AA (AFD)

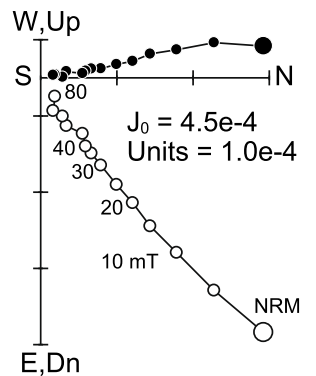

\section{HN33AB (ThD)}

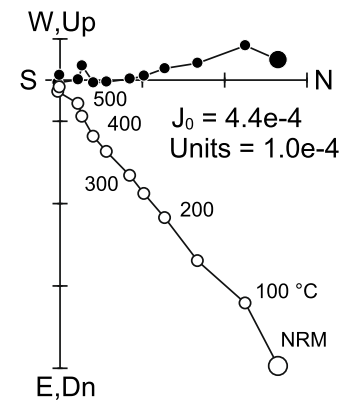

(d) $304.00 \mathrm{~m}$

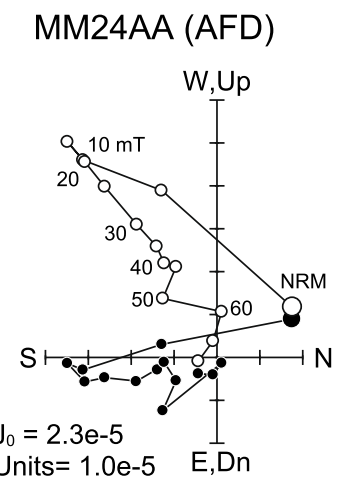

MM24AB (ThD)

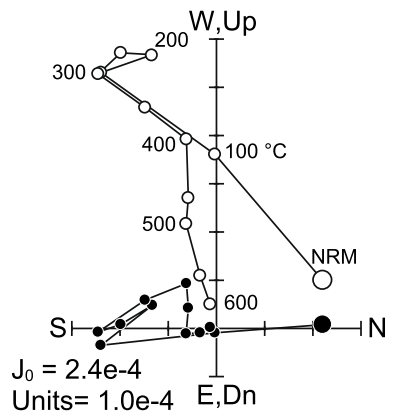

\section{(e) $297.00 \mathrm{~m}$}
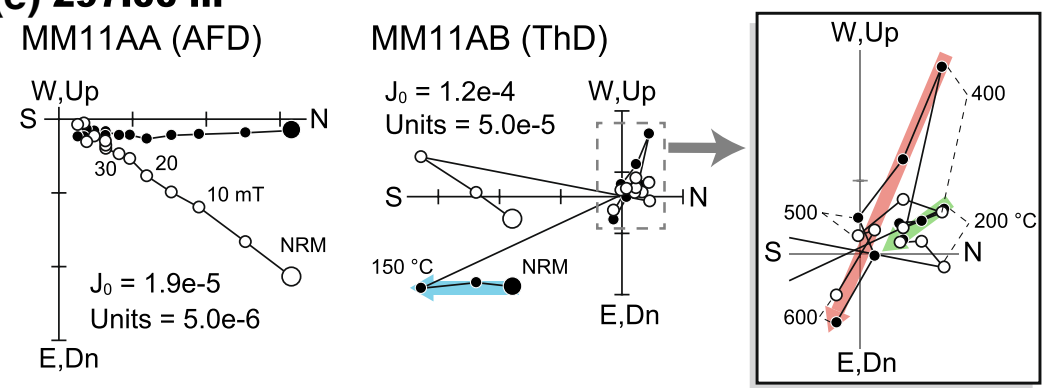

Fig. 6 Typical results of progressive alternating field demagnetization (pAFD) and progressive thermal demagnetization (pThD). a, e Results from the polarity transitions. $\mathbf{b}, \mathbf{c}$ Results from the normal palarity zones. $\mathbf{d}$ Result from the reversed polarity zone. Blue, light green, and red arrows in (e) represent low- $\left(0-150^{\circ} \mathrm{C}\right)$, medium- $\left(200-350^{\circ} \mathrm{C}\right)$, and high-temperature $\left(400-600{ }^{\circ} \mathrm{C}\right)$ declination components, respectively

is likely carried by goethite, which is characterized by a very high coercivity but a low Néel temperature of approximately $100-150{ }^{\circ} \mathrm{C}$ (O'Reilly 1984). The coercivity of goethite varies from $\sim 25$ to $\sim 314 \mathrm{mT}$ depending on its crystalline size (Dekkers 1989), and it could not be saturated even in an applied field of $57 \mathrm{~T}$ (Rochette et al. 2005). On the other hand, poorly crystalline nanophase goethite has low coercivity (Till et al. 2015, 2017). Although these studies indicate that the coercivity of goethite varies within a few orders of magnitude depending on the type of goethite, the secondary remanence carried by goethite is generally difficult to remove by AF demagnetization due to its high coercivity, and its thermal demagnetization is suitable. Therefore, the low-temperature component (Fig. 6e), which is probably composed of the chemical remanent magnetization (CRM) carried by goethite, may be dominant in the NRM from polarity transition horizons where pThD is needed to remove the CRM originating from goethite. Thus, we use the virtual geomagnetic pole (VGPs) from the ChRMs obtained from the $\mathrm{pThD}$ results to distinguish geomagnetic polarities (Additional file 1: Table S1).

The ChRM declinations from both demagnetization methods clearly indicate a clockwise rotation of declinations (Fig. 7b), which implies that the Anno Formation 


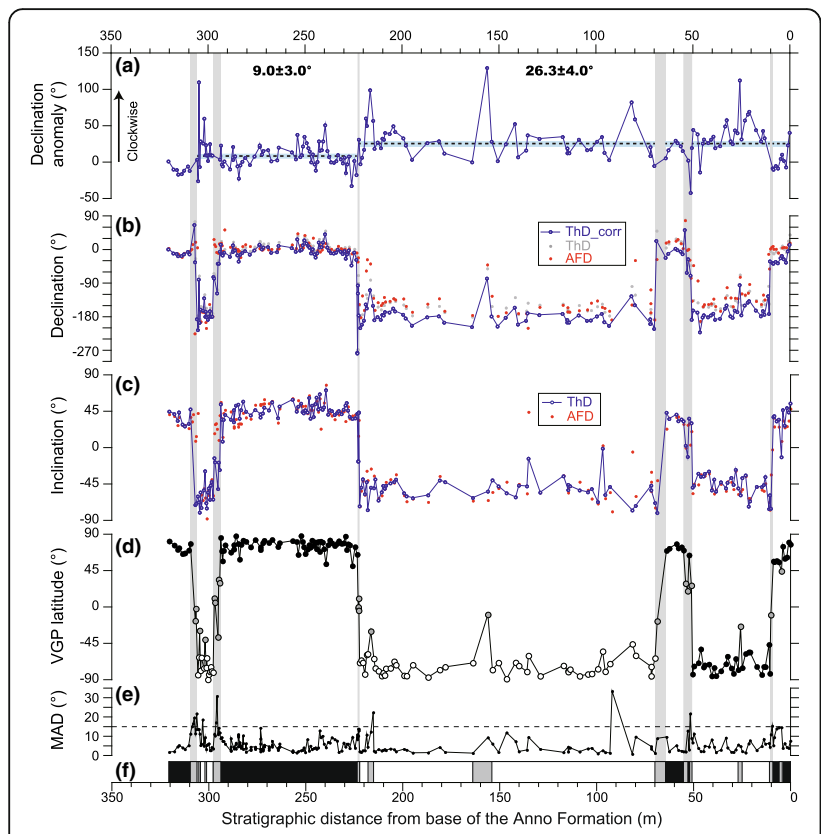

Fig. 7 Paleomagnetic direction profiles for the studied sequence. a Declination anomaly of declinations from true north $\left(0^{\circ}\right)$ deduced from the ChRM directions from pThD results. The horizontal dashed line and light blue shading indicate the average declination and its 95\% confidence limit for each stratigraphic interval, respectively. b Declinations of ChRMs from pAFD (red) and pThD (gray) and corrected declinations from $\mathrm{pThD}$ in which the average declinations are adjusted to true north (blue). c Inclinations of ChRM directions from pAFD (red) and pThD results (blue). $\mathbf{d}$ Virtual geomagnetic pole (VGP) latitudes from corrected ChRM directions from pThD results shown in (b) and (c). Black, white, and gray circles indicate normal, reversed, and intermediate polarities, respectively. e Maximum angular deviation (MAD) values of ChRMs from pThD results. The horizontal dashed line indicates MAD of $15^{\circ}$, which is the criterion for extracting of ChRMs in this study. $\mathbf{f}$ Polarities based on the VGP latitudes shown in (d). Black, white, and gray bars indicate normal, reversed, and intermediate polarities, respectively

along the Shikoma River experienced a regional tectonic rotation as described below. The ChRM declination anomalies (degrees from geographic north) from $\mathrm{pThD}$ are shown in Fig. 7a, where reversed polarity declinations were converted into normal polarity ones, except for the transitional zones, which are indicated as vertical gray bars. The declination anomalies undergo a stepwise change at the stratigraphic position of $223 \mathrm{~m}$. We took the averages and 95\% confidence limits of the declinations within their respective stratigraphic segments as follows: $26.3 \pm 4.0^{\circ}$ for 0 $223 \mathrm{~m}$ and $9.0 \pm 3.0^{\circ}$ for $223-307 \mathrm{~m}$. Consequently, we corrected the ChRM declinations by subtracting these averages before making VGP calculations. Then, we identified magnetic polarities based on the VGP latitudes, where latitudes of $>45^{\circ}$ denote normal polarity, latitudes of $<-45^{\circ}$ denote reversed polarity, and latitudes of $<|45|^{\circ}$ denote intermediate polarity. Therefore, we identified six polarity transitions over stratigraphic intervals of 9.1-10.9 m, 50.75-
$55.4 \mathrm{~m}, 64.2-70.1 \mathrm{~m}, 222.45-223.7 \mathrm{~m}, 294.1-298 \mathrm{~m}$, and 305.95-309.7 m (Fig. 7d, f; Additional file 1: Table S1).

\section{Magnetostratigraphy}

The VGP latitude variations plotted with tephra marker beds and other data obtained from previous studies and the resultant polarity reversal horizons in the Anno Formation are shown in Fig. 8 and Table 1. The calcareous nannofossil biostratigraphy of the Anno Formation was reconstructed by Kameo and Sekine (2013), who correlated the stratigraphic intervals of the tephra marker beds between An94 and An100, An117 and An128, and An146 and An158 to the last occurrence (LO) of Reticulofenestra pseudoumbilicus (3.79 Ma; Lourens et al. 2004), the LO of Sphenolithus spp. (3.65 Ma; Lourens et al. 2004), and the LO of Reticulofenestra minutula var. A (3.31-3.44 Ma; Kameo and Takayama 1999), respectively (Fig. 8a-c). We note that the LO of R. pseudoumbilicus is represented between An94 and An102 in Fig. 8 because An100 was not observed in the Shikoma River section. We correlated the polarity zones using the Geomagnetic Polarity Time Scale 2012 (Ogg 2012) based on the calcareous nannofossil stratigraphy (Kameo and Sekine 2013). The basal age of the Anno Formation was reported to be approximately $4.5 \mathrm{Ma}$ because the LO of Amaurolithus spp. correlates to just below Ky31 (Kameo et al. 2010), which is the uppermost tephra marker bed for the Kiyosumi Formation. Therefore, the lowermost polarity transition, which is observed at the 9.1-10.9 m interval between tephra marker beds An3 and An4, corresponds to the top of the Nunivak normal polarity subchronozone $(4.493 \mathrm{Ma})$. The polarity transitions observed at $50.75-55.4 \mathrm{~m}$ and $64.2-70.1 \mathrm{~m}$ are correlated to the bottom $(4.300 \mathrm{Ma})$ and top (4.187 Ma) of the Cochiti normal polarity subchronozone, respectively. These correlations are consistent with the fission track age of the An49 bed $(3.9 \pm 0.4 \mathrm{Ma}$; Tokuhashi et al. 2000) and the stratigraphic position of the LO of R. pseudoumbilicus (3.79 Ma), which is located approximately $70 \mathrm{~m}$ above this horizon (Kameo and Sekine 2013; Fig. 8c). The polarity transition at 222.45-223.7 m (between An129 and An130) is correlated to the Gilbert-Gauss boundary (3.596 Ma) because the interval between An117 and An128 corresponds to the LO of Sphenolithus spp. at $3.65 \mathrm{Ma}$ (Kameo and Sekine 2013; Fig. 8). Based on the stratigraphic position of the LO of $R$. minutula var. A (3.31-3.44 Ma) (Kameo and Sekine 2013), the polarity transitions at 294.1$298 \mathrm{~m}$ (just below An155) and 305.95-309.7 m (within An157) correspond to the bottom (3.330 Ma) and top (3.207 Ma) of the Mammoth reversed polarity subchronozone, respectively.

Tectonic rotations associated with the collision of the Izu-Bonin Arc with the Japanese Honshu Arc have been 


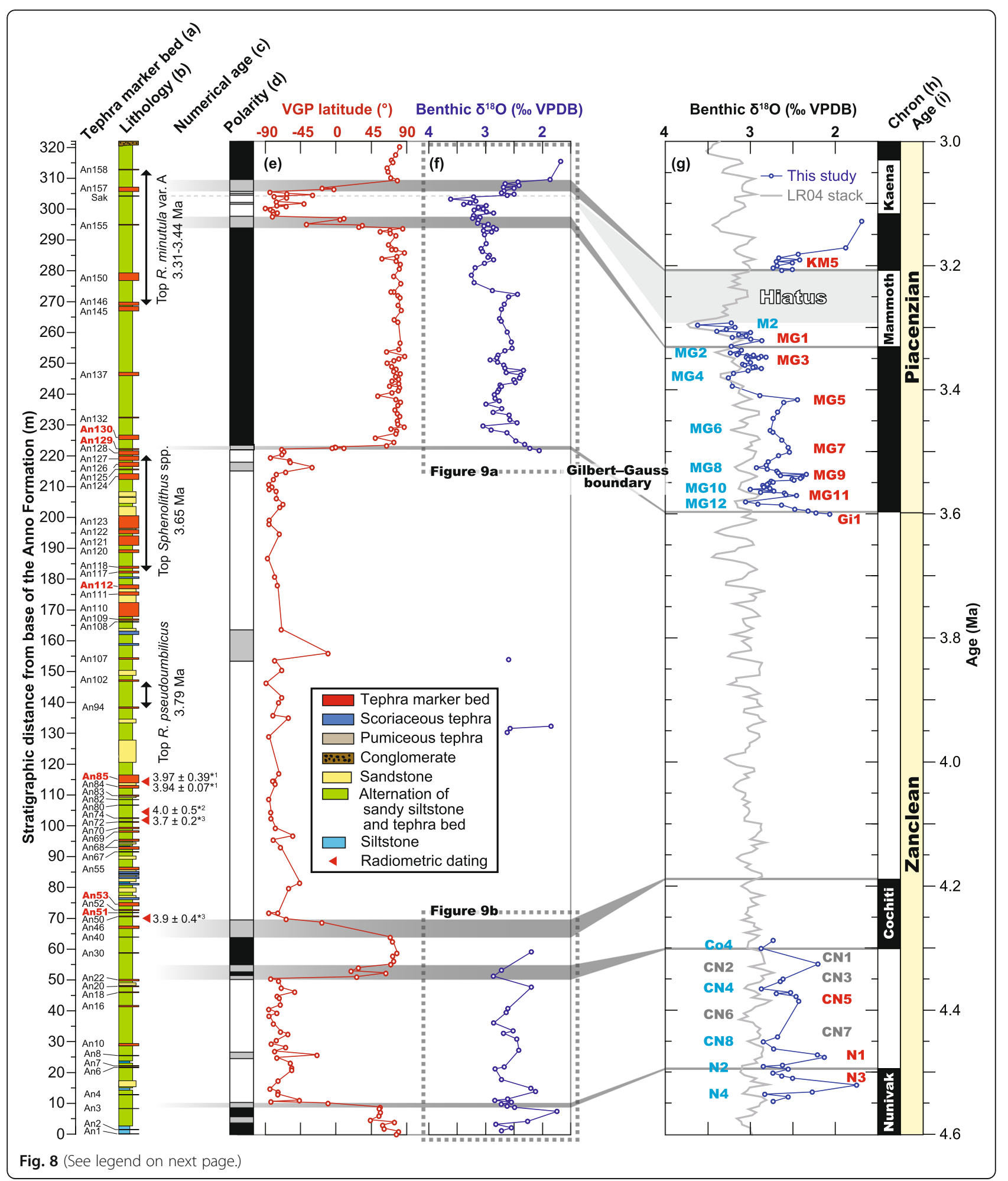


(See figure on previous page.)

Fig. 8 Summary of geochronological data for the Anno Formation. a Tephra marker beds and slump bed names. Red tephra marker beds indicate widespread tephra. b Lithological column for the study area. c Age constraints from previous studies. Vertical arrows indicate the calcareous nannofossil data from Kameo and Sekine (2013). Red triangles indicate radiometric ages for tephra marker beds from previous studies as follows: *1 An85 from Ueki et al. (2018), *2 An77 from Makinouchi et al. (1983), and *3 An73 and An49 from Tokuhashi et al. (2000). d Polarities based on the vertual geomagnetic pole (VGP) latitudes shown in Fig. 7d. Colored squares indicate polarities (black: normal; white: reversed; gray: intermediate). e Variation of the VGP latiutde shown in Fig. 7d. f Oxygen isotope stratigraphy of the Anno Formation. $\mathbf{g}$ Age model based on correlating the oxygen isotope profile of the Anno Formation with the LR04 benthic stack from Lisiecki and Raymo (2005). Letters and numbers represent marine isotope stages (MISs) from the LR04 benthic stack, and colors indicate the following: red: interglacial; blue: glacial; gray: stages not observed in this study. $\mathbf{h}$ Geomagnetic Polarity Time Scale 2012 from Ogg (2012).

i Pliocene subepoch based on Hilgen et al. (2012). Darker shading represents polarity reversal horizons. Light shading represents the hiatus of the Sak slump bed. Dashed gray boxes are shown in Fig. 9. VPDB Vienna Pee Dee Belemnite

recognized from Miocene-Pleistocene sediments in the Boso and Miura Peninsulas (Fig. 1a). Amano (1991) identified four accreted thrust-bounded blocks (i.e., the Kushigata-yama, Misaka, Tanzawa, and Izu blocks) within the Izu collision zone (ICZ) (Fig. 1a) and proposed that these blocks collided at 12, 9-7, 5-3, and $1 \mathrm{Ma}$, respectively. Based on paleomagnetic measurements in the southern Boso Peninsula, Kotake et al. (1995) reported an early Pleistocene clockwise rotation of $10-13^{\circ}$ associated with the Izu block collision. Yamamoto and Kawakami (2005) also reported that a late Miocene accretionary prism and early Pliocene trench-slope cover sediments in the southern Boso Peninsula underwent clockwise rotations of up to $80^{\circ}$ between 6.80 and $3.75 \mathrm{Ma}$ due to the collisions of the Tanzawa and/or Izu blocks. In the Miura Peninsula (Fig. 1a), the late Miocene sediments underwent clockwise rotation due to the Izu-Bonin Arc collision, which occurred after $4 \mathrm{Ma}$ (Yoshida et al. 1984). Moreover, the paleomagnetic record of Pliocene sediments during the Mammoth reversed polarity subchronozone in the Miura Peninsula shows a clockwise rotation of $28.4^{\circ}$ (Utsunomiya et al. 2017). Several paleomagnetic studies have implied that the collisions of the Izu-Bonin Arc affected the paleomagnetic directions of Miocene-Pleistocene sediments in the Boso and Miura Peninsulas. Based on our paleomagnetic record, the paleomagnetic declinations in the Anno Formation exhibit clockwise rotation, and the trend of declination anomalies varies at approximately

Table 1 Stratigraphic positions for the polarity reversal horizons

\begin{tabular}{lllll}
\hline Polarity boundary & \multicolumn{2}{l}{ Transitional zone } & Mid-thickness $(\mathrm{m})$ & Age $(\mathrm{Ma})$ \\
\cline { 2 - 4 } & Top $(\mathrm{m})$ & Bottom $(\mathrm{m})$ & & \\
\hline Mammoth top & 309.7 & 305.95 & 307.83 & 3.207 \\
Mammoth bottom & 298 & 294.1 & 296.05 & 3.330 \\
Gilbert-Gauss & 223.7 & 222.45 & 223.08 & 3.596 \\
Cochiti top & 70.1 & 64.2 & 67.15 & 4.187 \\
Cochiti bottom & 55.4 & 50.75 & 53.08 & 4.300 \\
Nunivak top & 10.1 & 9.9 & 10 & 4.493 \\
\hline
\end{tabular}

3.6 Ma (Figs. 7 and 8). These results indicate that the Anno Formation in the western Boso Peninsula was affected by the collisions of the Tanzawa and/or Izu blocks.

\section{Oxygen isotope stratigraphy}

Oxygen isotope analyses were mainly conducted on the 0 $59 \mathrm{~m}$ and 221-315 m stratigraphic intervals because only a small number of foraminiferal tests were obtained from the interval between 59 and $221 \mathrm{~m}$. The foraminifera species used for stable isotope analyses should be identical in a stratigraphic sequence because of differences in the isotopic values between different species, even if they are from the same rock sample. In this study, there are three dominant benthic foraminifera, Uvigerina spp., B. quadrilatera, and $M$. pompiloides. Therefore, we carried out an interspecies correlation to calibrate the $\delta^{18} \mathrm{O}$ values obtained from $B$. quadrilatera $\left(\delta^{18} \mathrm{O}_{\mathrm{Bo}}\right)$ and M. pompiloides $\left(\delta^{18} \mathrm{O}_{\mathrm{Me}}\right)$ to the $\delta^{18} \mathrm{O}$ values of Uvigerina spp. $\left(\delta^{18} \mathrm{O}_{\mathrm{Uv}}\right)$, which is a genus that is globally used to construct oxygen isotope stratigraphies. We extracted 18 sets from $B$. quadrilatera and $M$. pompiloides and 11 sets from $B$. quadrilatera and Uvigerina spp. in which these 2 species coexist in the same rock sample, and we obtained the average differences between these pairs of species as follows: $\delta^{18} \mathrm{O}_{\mathrm{Bo}}-\delta^{18} \mathrm{O}_{\mathrm{Me}}=0.56 \pm$ $0.09 \%$ and $\delta^{18} \mathrm{O}_{\mathrm{Bo}}-\delta^{18} \mathrm{O}_{\mathrm{Uv}}=-0.16 \pm 0.22 \%$ (errors are standard deviations). Therefore, we corrected $\delta^{18} \mathrm{O}_{\mathrm{Bo}}$ and $\delta^{18} \mathrm{O}_{\mathrm{Me}}$ to $\delta^{18} \mathrm{O}_{\mathrm{Uv}}$ using additional values of $0.16 \%$ and $0.72 \%$, respectively (Additional file 2: Table S2).

The resultant oxygen isotope profile fluctuates between 1.68 and $3.61 \%$, with an average value of $2.72 \%$ (Fig. 8; Additional file 3: Table S3). To reconstruct an age model for the Anno Formation, our oxygen isotope profile was correlated with the LR04 stack as a target curve (Lisiecki and Raymo 2005). Based on the visual correlation between the oxygen isotope profile of the Anno Formation and the LR04 stack, we assigned 24 tie points where the LR04 stack exhibited either a peak or a trough to complete the magnetostratigraphy (Fig. 9; Table 1). Based on the resultant age model, the stratigraphic interval between tephra marker beds An1 and An30 corresponds to marine isotope stage (MIS) N4 through Co4, although MIS CN1, $\mathrm{CN} 2, \mathrm{CN} 3, \mathrm{CN} 6$, and $\mathrm{CN} 7$ are missing because they are 


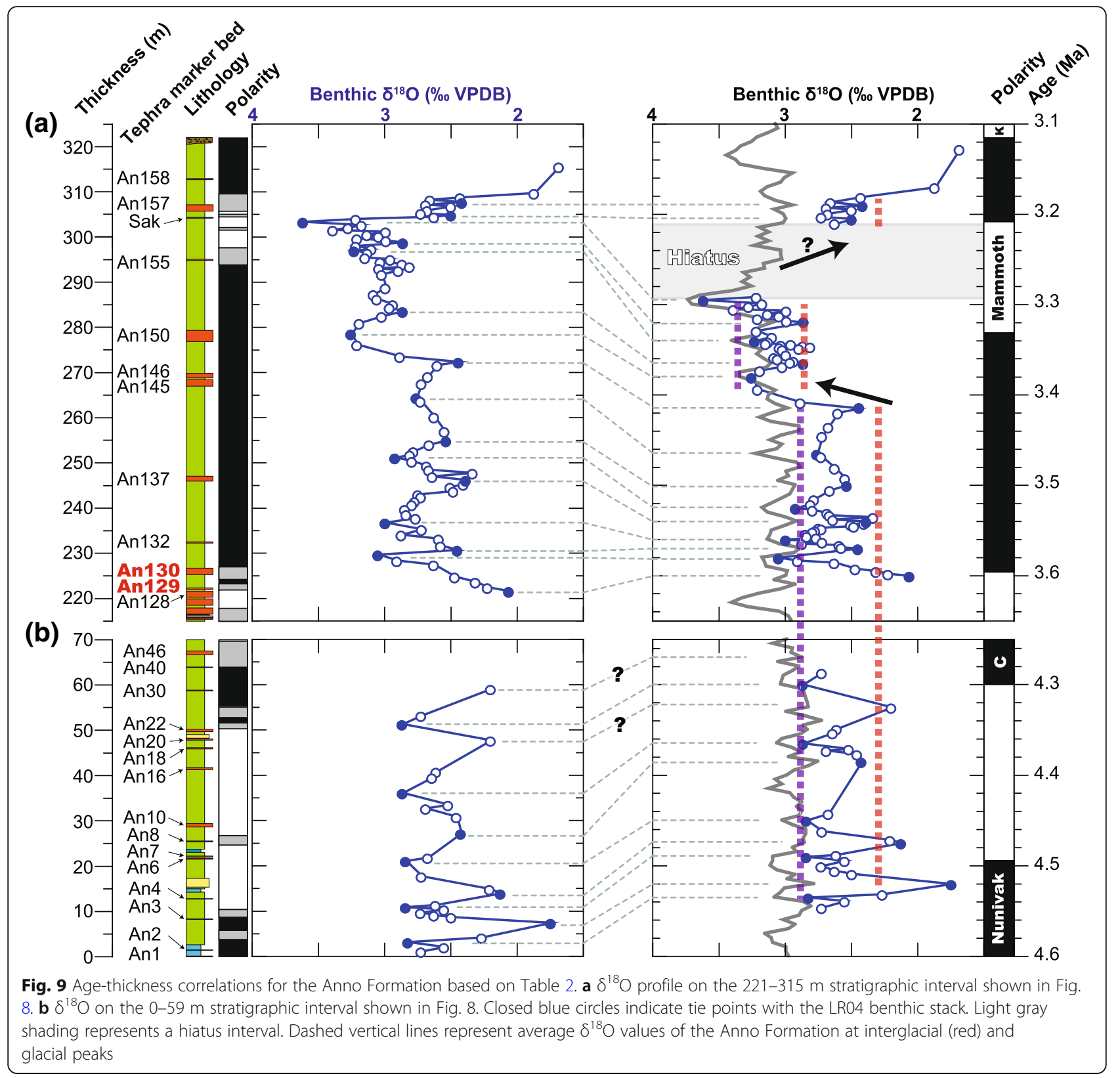

barren of fossil foraminifera (Table 2). In contrast, in the oxygen isotope profile for the upper Anno Formation, foraminifera were yielded from almost every horizon, which correspond to MIS Gi1 through KM5 (Table 2). However, MIS M1 and KM6 are missing because of the hiatus by a slump bed known as the Sak slump (Figs. 3, 8 and 9).

Nakajima and Watanabe (2005) reported that the Sak slump, which is located between tephra marker beds An155 and An157 in the uppermost Anno Formation along the Shikoma and Minato Rivers (Fig. 1c), has eroded strata with a thickness of approximately 8-15 m. The An156 bed, which has been recognized in other sections, is missing along the
Shikoma and Minato Rivers (Nakajima and Watanabe 2005; Figs. 8 and 9). The polarity transitions that correspond to the bottom and top of the Mammoth reversed polarity subchronozone contain transitional features with VGP paths that traverse intermediate latitudes across both boundaries (Fig. 7). The $\delta^{18} \mathrm{O}$ value at the $303.4 \mathrm{~m}$ horizon (MM23 in Additional file 3: Table S3), which is the highest value in our oxygen isotope record, should correspond to MIS M2 (Fig. 8), which is one of the four largest Pliocene short cooling events (De Schepper et al. 2014). These observations suggest that the slump bed is intercalated within the Mammoth reversed 
Table 2 Age model based on the oxygen isotope record for the Anno Formation

\begin{tabular}{|c|c|c|c|}
\hline Sample name & Thickness (m) & Age (Ma) & MIS \\
\hline MM32 & 307.7 & 3.19 & KM5 \\
\hline MM26 & 304.9 & 3.20 & KM5 \\
\hline MM23 & 303.35 & 3.30 & M2 \\
\hline MM14 & 298.8 & 3.32 & MG1 \\
\hline MM11 & 297 & 3.34 & MG2 \\
\hline HN06 & 283.6 & 3.37 & MG3 \\
\hline HN09 & 278.6 & 3.38 & MG4 \\
\hline HN12 & 272.4 & 3.41 & MG5 \\
\hline HN17 & 264.5 & 3.46 & MG6 \\
\hline $\mathrm{HN} 22$ & 254.9 & 3.50 & MG7 \\
\hline HN26 & 251.2 & 3.53 & MG8 \\
\hline HN32 & 246.2 & 3.54 & MG9 \\
\hline HN43 & 236.8 & 3.56 & MG10 \\
\hline HN48 & 230.8 & 3.57 & MG11 \\
\hline HN49 & 229.7 & 3.58 & MG12 \\
\hline HN57 & 221.7 & 3.60 & Gi1 \\
\hline HN148 & 51.3 & 4.30 & $\mathrm{Co} 4$ \\
\hline HN91 & 47.7 & 4.33 & CN1? \\
\hline HN99 & 36.1 & 4.37 & CN4 \\
\hline HN105 & 27.2 & 4.39 & CN5 \\
\hline HN110 & 21.1 & 4.45 & CN8 \\
\hline HN113 & 13.9 & 4.48 & N1 \\
\hline HN149 & 10.9 & 4.49 & N2 \\
\hline HN119 & 7.4 & 4.52 & N3 \\
\hline HN123 & 3.2 & 4.54 & N4 \\
\hline
\end{tabular}

polarity subchronozone between MIS M2 and KM5. Therefore, the Sak slump bed may have eroded strata for a duration of approximately $90 \mathrm{kyr}$, which extends from immediately after the peak of MIS M2 (3.295 Ma) to just before the polarity switch at the termination of the Mammoth subchron (3.207 Ma).

An age model based on our chronostratigraphy of the Anno Formation is shown with the calcareous nannofossil bioevents (Kameo and Sekine 2013) and radiometric ages of tephra marker beds (Makinouchi et al. 1983; Tokuhashi et al. 2000; Ueki et al. 2018) in Fig. 10. The sedimentation rates estimated from our chronostratigraphy vary between 2 and $61 \mathrm{~cm} / \mathrm{kyr}$. The horizon with the lowest value corresponds to the hiatus mentioned above.

\section{Pliocene paleoceanographic implications for the northwestern Pacific Ocean}

The amplitude of our $\delta^{18} \mathrm{O}$ profile is larger than that of the LR04 stack within the same time interval, and it is suppressed after 3.4 Ma (Fig. 9). Comparing the average $\delta^{18} \mathrm{O}$ values of each interglacial and glacial between our $\delta^{18} \mathrm{O}$ record and the LR04 stack until 3.4 Ma reveals that the average difference $(0.63 \%)$ at interglacial peak points is obviously larger than that $(0.24 \%$ o $)$ at glacial peak points (Fig. 9). On the other hand, from 3.4 to $3.3 \mathrm{Ma}$, the average differences at interglacial $(0.25 \%)$ and glacial peaks $(0.14 \%)$ are more comparable than those until 3.4 Ma (Fig. 9). This observation implies that a warm water mass and/or a lower- $\delta^{18} \mathrm{O}$ seawater component influenced only interglacial benthic $\delta^{18} \mathrm{O}$ until 3.4 Ma. The local hydrographic variations during interglacial periods until 3.4 Ma correspond to $\sim 2.7^{\circ} \mathrm{C}$ higher bottom water temperatures (deduced by $-0.23 \% /{ }^{\circ} \mathrm{C}$; Erez and Luz 1983 ) or $\sim 1.2$ psu lower salinity (deduced by $+0.52 \%$ / psu; Oba et al. 2006) relative to the global average. The depositional water depth of the Anno Formation is believed to be between 1000 and $2800 \mathrm{~m}$ based on benthic foraminiferal assemblages (Hatta and Tokuhashi 1984). This is comparable to the average core depth of approximately $2800 \mathrm{~m}$ used in the LR04 stack between 3 and $4.5 \mathrm{Ma}$ (Lisiecki and Raymo 2005). Considering the paleodepth of the sedimentary basin, these variations may have been attributed to deep or intermediate waters.

In the modern deep North Pacific Ocean, the Pacific Deep Water (PDW) is recognized at depths of 2000$3000 \mathrm{~m}$ as the return flow of the south-sourced Circumpolar Deep Water (CDW) (e.g., Mantyla and Reid 1983). In addition, a north-sourced intermediate water characterized by a salinity minimum at a depth of $\sim 300-800 \mathrm{~m}$ has been recognized and defined as the North Pacific Intermediate Water (NPIW) (Reid 1965). A deep-water body is not generated in the modern North Pacific. On the other hand, Burls et al. (2017) suggested that the formation of subarctic North Pacific Deep Water (NPDW), which was warmer and fresher than modern deep-water in the North Pacific, constructed a Pacific meridional overturning circulation (PMOC) cell during the Pliocene based on complementary measurement and modeling evidence. They also reported orbitally paced maxima in the calcium carbonate mass accumulation rate $\left(\mathrm{CaCO}_{3} \mathrm{MAR}\right)$, with accompanying pigment and total organic carbon measurements supporting deep-ocean ventilation-driven preservation as their cause (Burls et al. 2017). Enhanced north-sourced deep-water ventilation during the early Pliocene has also been recognized in the northeastern Pacific based on benthic $\delta^{13} \mathrm{C}$ records (Kwiek and Ravelo 1999; Ravelo and Andreasen 2000). Moreover, a deep western boundary current at a water depth of 1000-2000 m flowing along the western margin of the North Pacific Ocean was simulated (Burls et al. 2017). These results imply that the Pliocene warm NPDW could have migrated into the sedimentary basin of the Anno Formation. This local hydrographic influence was suppressed at approximately 3.4 Ma (Fig. 9), when benthic $\delta^{13} \mathrm{C}$ records in the northeastern Pacific decreased, and 


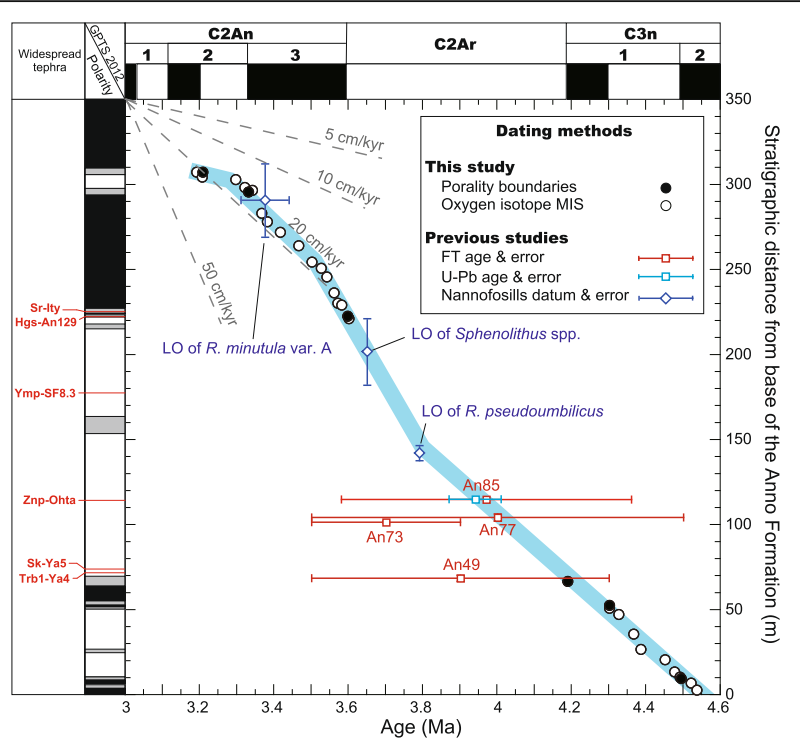

Fig. 10 Age versus thickness diagram for the Anno Formation. Data points are based on the polarity reversal events and marine isotope stages (MISs) listed in Tables 1 and 2, in addition to calcareous nannofossil bioevents (Kameo and Sekine 2013) and radiometric ages (Makinouchi et al. 1983; Tokuhashi et al. 2000; Ueki et al. 2018). The Geomagnetic Polarity Time Scale (GPTS) 2012 is based on Ogg (2012)

south-sourced deep-water was dominant (Kwiek and Ravelo 1999; Mix et al. 1995). These observations imply that the Pliocene deep Pacific circulation began to cease in stages, eventually becoming similar to its modern mode at approximately 3.4 Ma.

In the $\mathrm{CaCO}_{3} \mathrm{MAR}$ record (Haug et al. 1995) used in Burls et al. (2017), an interval of poor $\mathrm{CaCO}_{3}$ preservation has been recognized around $4 \mathrm{Ma}$, which corresponds to the foraminifera-barren interval observed in the middle Anno Formation between 3.6 and 4.3 Ma (Fig. 8). Interestingly, a hiatus missing depositions between 3.6 and 4.3 Ma was recognized from the Antarctic Drilling Program's (ANDRILL) AND-1B core from the Ross Embayment, which implies non-glacial erosion or non-deposition, possibly due to bottom water currents that were invigorated by modest ice sheet expansion during this time interval (McKay et al. 2012). In addition, a modeling study showed that ice advances in the Pacific sector of East Antarctica could invigorate the expansion of CDW into the deep North Pacific basin (Hill et al. 2017). Therefore, the lack of foraminifera in the middle Anno Formation is presumably explained by the shallowing of the CCD due to the enhanced penetration of south-sourced deep-water into the sedimentary basin instead of north-sourced deep-water.

\section{Conclusions}

Based on paleomagnetic and oxygen isotopic data, the new, integrated chronostratigraphy of the Pliocene Anno Formation, which is located in the Boso Peninsula, central Japan, reveals the relationship between the tephra marker beds, Pliocene MISs, and geomagnetic reversal boundaries within the Anno Formation. Rock-magnetic experiments reveal that specimens from the Anno Formation contain vortex state (PSD) (titano) magnetites that can preserve reliable paleomagnetic signals. Paleomagnetic results illustrate that pAFD cannot remove the secondary magnetizations of polarity transition intervals and that $\mathrm{pThD}$ was suitable for reconstructing the magnetostratigraphy of the Anno Formation.

The Anno Formation corresponds to the period from the Nunivak normal polarity subchron to Chron C2An.2n, which corresponds to just after the Mammoth reversed polarity subchron. Although fossil foraminifera are not found in the middle Anno Formation, our oxygen isotope records from the upper and lower Anno Formation reveal glacial-interglacial cycles. However, the amplitude of our $\delta^{18} \mathrm{O}$ profile is much larger than that of the LR04 stack, which is associated with similar to slightly lower glacial values and much lower interglacial values. The paleodepth of the Anno Formation based on benthic foraminiferal assemblage analyses and our oxygen isotope stratigraphy imply that the sedimentary basin during the Pliocene was occupied by water with lower- $\delta^{18} \mathrm{O}$ values and/or by a warmer water mass during interglacial periods compared with the global average deep-water variation.

\section{Additional files}

Additional file 1: Table S1. Directions of ChRM components and VGPS from the Anno Formation within the study area analyzed at the NMNS 
and KCC. Corrected declinations were estimated by correcting the back anomalies of declinations through rotation. (XLSX $29.9 \mathrm{~kb}$ )

Additional file 2: Table S2. Oxygen isotope data used for the interspecies correlation. (XLSX $11.4 \mathrm{~kb}$ )

Additional file 3: Table S3. Oxygen isotope values from the Anno Formation within the study area analyzed at the NIPR and KCC. Corrected $\delta^{18} \mathrm{O}$ data represent the values after the interspecies correlation. Average $\delta^{18} \mathrm{O}$ values are used for the oxygen isotope stratigraphy. (XLSX 22.6 kb)

\section{Abbreviations}

AFD: Alternating field demagnetization; CCD: Calcite compensation depth CDW: Circumpolar Deep Water; ChRM: Characteristic remanent magnetization; LO: Last occurrence; MD: Multi-domain; MIS: Marine isotope stage; NPDW: North Pacific Deep Water; NPIW: North Pacific Intermediate Water; NRM: Natural remanent magnetization; ODP: Ocean Drilling Program; PDW: Pacific Deep Water; PMOC: Pacific meridional overturning circulation; PSD: Pseudo-single domain; SD: Single domain; ThD: Thermal demagnetization; VGP: Virtual geomagnetic pole; VPDB: Vienna Pee Dee Belemnite

\section{Acknowledgments}

We thank T. Nakajima (Geological Survey of Japan, AIST) for providing precious geological data; T. Shinozaki for advice about the distributions of tephra beds; M. Ikehara and Y. Yamamoto for support with oxygen isotope and rock- and paleomagnetic measurements at the Center for Advanced Marine Core Research, Kochi University through a joint-use system (16A023/ 16B021, 17A038/17B038 and 18A010/18B009); Y. Suganuma for support with rock- and paleomagnetic measurements at the National Institute of Polar Research (NIPR); Y. Kubota and N. Suzuki for support with oxygen isotope analyses at the National Museum of Nature and Science; T. Konishi (Ibaraki University) for their cooperation with a magnetic measurement; and J. Hosoi (Geological Survey of Japan, AIST), M. Kawamata (NIPR), M. Sugaya, T. Maruoka, Y. Ikeda, T. Maeda, S. Mitsuzuka, E. Kanazawa, and Y. Shimota (Ibaraki University) for their support with sampling. We would also like to thank two reviewers and the editor of Progress in Earth and Planetary Science for their constructive comments, which greatly improved the manuscript.

\section{Funding}

This study was supported by a JSPS KAKENHI grant (16H04068) awarded to $\mathrm{MO}$ and a Fukada Grant-in-Aid from the Fukada Geological Institute awarded to $\mathrm{YH}$.

\section{Availability of data and materials}

Please contact author for data requests.

\section{Authors' contributions}

$\mathrm{YH}$ and $\mathrm{MO}$ wrote the manuscript, coordinated the structure of the paper, and carried out the geological fieldwork. YH carried out the experimental measurements and analyzed the data. Both authors read and approved the final manuscript.

\section{Competing interests}

The authors declare that they have no competing interests.

\section{Publisher's Note}

Springer Nature remains neutral with regard to jurisdictional claims in published maps and institutional affiliations.

\section{Author details}

${ }^{1}$ Graduate School of Science and Engineering, Ibaraki University, 2-1-1 Bunkyo, Mito, Ibaraki 310-8512, Japan. ²Department of Environmental Science, Ibaraki University, 2-1-1 Bunkyo, Mito, Ibaraki 310-8512, Japan.

Received: 19 June 2018 Accepted: 5 December 2018

Published online: 21 January 2019

\section{References}

Amano K (1991) Multiple collision tectonics of the south Fossa magna in Central Japan. Mod Geol 15:315-329
Blow WH (1969) Late middle Eocene to recent planktonic foraminiferal biostratigraphy. In: Bronnimann P, Renz HH (eds). Proc. 1st Internat. Conf. Planktonic Microfossils, Geneva, pp 199-422

Bowles JA, Jackson MJ, Berquo TS, Sølheid PA, Gee JS (2013) Inferred time- and temperature-dependent cation ordering in natural titanomagnetites. Nat Commun 4:1916. https://doi.org/10.1038/ncomms2938

Burls NJ, Fedorov AV, Sigman DM, Jaccard SL, Tiedemann R, Haug GH (2017) Active Pacific meridional overturning circulation (PMOC) during the warm Pliocene. Sci Adv 3:e1700156. https://doi.org/10.1126/sciadv.1700156

Day R, Fuller M, Schmidt VA (1977) Hysteresis properties of titanomagnetites: grain size and composition dependence. Phys Earth Planet Int 13:260-267. https://doi.org/10.1016/0031-9201(77)90108-X

De Schepper S, Gibbard PL, Salzmann U, Ehlers J (2014) A global synthesis of the marine and terrestrial evidence for glaciation during the Pliocene epoch. Earth Sci Rev 135:83-102. https://doi.org/10.1016/j.earscirev.2014.04.003

Dekkers MJ (1989) Magnetic properties of natural goethite-l. Grain-size dependence of some low- and high-field related rockmagnetic parameters measured at room temperature. Geophys J 97:323-340. https://doi.org/10. 1111/j.1365-246X.1989.tb00504.x

Dunlop DJ (2002) Theory and application of the Day plot (Mrs/Ms versus Hcr/Hc), 1. Theoritical curves and tests using titanomagnetite data. J Geophys Res 107. https://doi.org/10.1029/2001JB000486

Erez J, Luz B (1983) Experimental paleotemperature equation for planktonic foraminifera. Geochim Cosmochim Acta 47:1025-1031. https://doi.org/10. 1016/0016-7037(83)90232-6

Haga M, Kotake N (1996) Diatom age of the lower part of the Miocene Amatsu formation, Boso peninsula, southern-central Japan. J Geol Soc Jpn 102:758760 (in Japanese with English abstract)

Harrison RJ, Feinberg JM (2008) FORCinel: an improved algorithm for calculating firstorder reversal curve distributions using locally weighted regression smoothing. Geochem Geophys Geosyst 9. https:/doi.org/10.1029/2008GC001987

Hatta A, Tokuhashi S (1984) On the foraminiferal assemblage in the hemipelagic mudstone of the Kiyosumi and anno formations, Boso Peninsula, Japan. News Osaka Micropaleontologist (NOM) 12:17-32 (in Japanese with English abstract)

Haug GH, Maslin MA, Sarnthein M, Stax R, Tiedemann R (1995) Evolution of Northwest Pacific sedimentation patterns since $6 \mathrm{Ma}$ (Site 882). In: Rea DK, Basov IA, Scholl DW, Allan JF (eds) Proc Ocean Drill Prog, Sci Res, vol 145, pp 293-314

Hilgen FJ, Lourence LJ, van Dam JA (2012) The Neogene period. In: Gradstein FM Ogg JG, Schmitz MD, Ogg GM (eds) The geologic time scale 2012, vol 2. Elsevier, Boston, pp 923-978

Hill DJ, Bolton KP, Haywood AM (2017) Modelled ocean changes at the PlioPleistocene transition driven by Antarctic ice advance. Nat Commun 8:14376. https://doi.org/10.1038/ncomms14376

Hunt CP, Moskowitz BM, Banerjee SK (1995) Magnetic propaties of rock and mineral. In: Thomas JA (ed) Rock physics and phase relations: a handbook of physical constant. American Geophysical Union, Washington DC, p 236

Hurford AJ (1990a) International-union-of-geological-sciences subcommission on geochronology recommendation for the standardization of fission-track dating calibration and data reporting. Nucl Tracks Rad Meas 17:233-236. https://doi.org/10.1016/1359-0189(90)90040-5

Ito M, Kameo K, Satoguchi Y, Masuda F, Hiroki Y, Takano O, Nakajima T, Suzuki N (2016) Neogene-Quaternary sedimentary successions. In: Moreno T, Wallis S, Kojima T, Gibbons W (eds) The geology of Japan. Geological Society, London

Kameo K, Mita I, Fujioka M (2002) Calcareous nannofossil biostratigraphy of the Amatsu Formation (Middle Miocene to Lower Pliocene), Awa Group, distributed in the central part of the Boso Peninsula, central Japan. J Geol Soc Jpn 108:813-828 (in Japanese with English abstract)

Kameo K, Sekine T (2013) Calcareous nannnofossil biostratigraphy and geologic age of the Anno Formation, the Awa Group, in the Boso Peninsula, Central Japan. J Geol Soc Jpn 119:410-420 (in Japanese with English abstract)

Kameo K, Shindo R, Takayama T (2010) Calcareous nannofossil biostratigraphy and geologic age of the Kiyosumi Formation of the Awa Group, Boso Peninsula, central Japan: age determination based on size variations of Reticulofenestra specimens. J Geol Soc Jpn 116:563-574 (in Japanese with English abstract)

Kameo K, Takayama T (1999) Biostratigraphic significance of sequential size variation of the calcareous nannofossil genus Reticulofenestra in the Upper Pliocene of the North Atlantic. Mar Micropaleontol 37:41-52. https://doi.org/ 10.1016/S0377-8398(99)00009-2

Kotake N, Koyama M, Kameo K (1995) Magnetostratigraphy and biostratigraphy of the Plio-Pleistocene Chikura and Toyofusa groups, southernmost part of 
the Boso Peninsula, central Japan. J Geol Soc Jpn 101:515-531 (in Japanese, with English abstract)

Kurokawa K, Higuchi Y (2004) Tephrostratigraphy and correlations of some Pliocene tephra beds (4-2 Ma) in the Niigata region, especially on the distribution of the tsp tephra bed, and widearea correlations to the YT tephra beds in the Himi group and the Boso Peninsula, central Japan. Mem Fac Educ Hum Sci (Nat Sci) Niigata Univ 7:13-78 (in Japanese with English abstract)

Kwiek PB, Ravelo AC (1999) Pacific Ocean intermediate and deep water circularion during the Pliocene. Palaeogeogr Palaeoclimatol Palaeoecol 154: 191-217. https://doi.org/10.1016/S0031-0182(99)00111-X

Lisiecki LE, Raymo ME (2005) A Pliocene-Pleistocene stack of 57 globally distributed benthic $\delta^{18} \mathrm{O}$ records. Paleoceanogr 20(1):PA1003. https://doi.org/ 10.1029/2004PA001071

Lourens L, Hilgen F, Shackleton NJ, Laske J, Wilson D (2004) The Neogene period. In: Gradstein FM, Ogg JG, Smith AG (eds) A Geologic Time Scale 2004. Cambridge University Press, Cambridge

Lunt DJ, Haywood AM, Schmidt GA, Salzmann U, Valdes PJ, Dowsett HJ (2010) Earth system sensitivity inferred from Pliocene modelling and data. Nat Geosci 3:60-64. https://doi.org/10.1038/ngeo706

Makinouchi T, Danhara T, Isoda T (1983) Fission-track ages of the Tokai group and associate formations in the east coast area of Ise Bay and their significance in geohistory. J Geol Soc Jpn 89:257-270 (in Japanese with English abstract)

Mantyla AW, Reid JL (1983) Abyssal characteristics of the World Ocean waters. Deep Sea Res A 30:805-833. https://doi.org/10.1016/0198-0149(83)90002-X

Martini E (1971) Standard Tertiary and Quaternary calcareous nannoplancton zonation. In: Farinacci A (ed) Proceedings of the Second Planktonic Conference, Roma, 1970. Tecnoscienze, Roma

McKay R, Naish T, Carter L, Riesselman C, Dunbar R, Sjunneskog C, Winter D, Sangiorgi F, Warren C, Pagani M, Schouten S, Willmott V, Levy R, DeConto R, Powell RD (2012) Antarctic and Southern Ocean influences on Late Pliocene global cooling. Proc Natl Acad Sci 109:6423-6428. https://doi.org/10.1073/pnas.1112248109

Mitsunashi T, Suda Y (1980) The geological map of Japan, scale 1:200000, Otaki. Geol Surv Japan, Tsukuba

Mix AC, Pisias NG, Rugh W, Wilson J, Morey A, Hagelberg TK (1995) Benthic foraminifer stable record from site 849 (0-5 Ma): local and global climate changes. In: Pisias NG, Mayer LA, Janecek TR, Palmer-Julson A, van Andel TH (eds) Proc Ocean Drill Prog, Sci Res, vol 138, pp 371-412

Mochizuki N, Oda H, Ishizuka O, Yamazaki T, Tsunakawa H (2011) Paleointensity variation across the Matuyama-Brunhes polarity transition: observations from lavas at PunaruuValley, Tahiti. J Geophys Res 116:B06103. https://doi.org/10.1029/ 2010JB008093

Naish T, Powell R, Levy R, Wilson G, Scherer R, Talarico F, Krissek L, Niessen F, Pompilio M, Wilson T, Carter L, DeConto R, Huybers P, Mckay R, Pollard D, Ross J, Winter D, Barrett P, Browne G, Cody R, Cowan E, Crampton J, Dunbar G, Dunbar N, Florindo F, Gebhardt C, Graham I, Hannah M, Hansaraj D, Harwood DM et al (2009) Obliquity-paced Pliocene West Antarctic ice sheet oscillations. Nature 458:322-328. https://doi.org/10.1038/nature07867

Nakajima T (1978) Sedimentary environment of flysch sediments in the Boso Peninsula, Japan - relationship between flysch and its marginal facies of the Kiwada, Kurotaki and Anno Formations. J Geol Soc Jpn 84:645-660 (in Japanese with English abstract)

Nakajima T, Makimoto H, Hirayama J, Tokuhashi S (1981) Geology of Kamogawa District. Quadrangle series, 1:50000. Geol Surv Japan, Tsukuba. In: Japanese with English abstract

Nakajima T, Watanabe M (2005) Geology of Futtsu District. Quadrangle series, 1: 50000. Geol Surv Japan, Tsukuba. In: Japanese with English abstract

Natural History Museum and Institute, Chiba (ed) (1993) Catalog of Key Tuff Beds in the Lower Part of the Anno Formation, the Miura Group, the Edition of 1992. Natural History Museum and Institute, Chiba, Chiba (in Japanese)

Natural History Museum and Institute, Chiba (ed) (1995) Catalog of Key Tuff Beds in the Middle Part of the Anno Formation, the Miura Group, the Edition of 1994. Natural History Museum and Institute, Chiba, Chiba (in Japanese)

Natural History Museum and Institute, Chiba (ed) (1996) Catalog of Key Tuff Beds in the Upper Part of the Anno Formation, the Miura Group, the Edition of 1995. Natural History Museum and Institute, Chiba, Chiba (in Japanese)

Niitsuma N (1976) Magnetic stratigraphy in the Boso Peninsula. J Geol Soc of Jpn 82:163-181 (in Japanese with English abstract)

O'Reilly W (1984) Rock and mineral magnetism. Blackie and Son Ltd, Glasgow

Oba T, Irino T, Yamamoto M, Murayama M, Takamura A, Aoki K (2006)

Paleoceanographic change off central Japan since the last 144,000 years based on high-resolution oxygen and carbon isotope records. Glob Planet Change 53:5-20. https://doi.org/10.1016/.j.gloplacha.2006.05.002

Oda M (1977) Planktonic foraminiferal biostratigraphy of the Late Cenozoic sedimentary sequences, Central Honshu, Japan. In: Science reports of Tohoku University, 2nd series (geology), vol 48, pp 1-72

Ogg JG (2012) Geomagnetic polarity time scale. In: Gradstein FM, Ogg JG, Schmitz MD, Ogg GM (eds) The geologic time scale 2012, vol 1. Elsevier, Boston, p 435

Okada H, Bukry D (1980) Supplementary modification and introduction of code numbers to low latitude cocolith biostratigraphy zonation (Bukry, 1973; 1975). Mar Micropaleontol 5:321-325. https://doi.org/10.1016/03778398(80)90016-X

Özdemir Ö, Dunlop DJ (2010) Hallmarks of maghemitization in low-temperature remanence cycling of partially oxidized magnetite nanoparticles. J Geophys Res 115:B02101. https://doi.org/10.1029/2009JB006756

Özdemir Ö, Dunlop DJ, Moskowitz BM (1993) The effect of oxidation on the Verwey transition in magnetite. Geophys Res Lett 20:1671-1674. https://doi. org/10.1029/93GL01483

Pike CR, Roberts AP, Verosub KL (1999) Characterizing interactions in fine magnetic particle systems using first order reversal curves. J App Phys 85: 6660-6667. https://doi.org/10.1063/1.370176

Qiu B (2001) Kuroshio and Oyashio currents. In: Steele JH, Thorpe SA, Turekian KK (eds) Encyclopedia of ocean science. Academic Press, London

Ravelo AC, Andreasen DH (2000) Enhanced circulation during a warm period. Geophys Res Lett 27:1001-1004. https://doi.org/10.1029/1999GL007000

Reid JL (1965) Intermediate waters of the Pacific Ocean, Johns Hopkins oceanographic studies no.2. Johns Hopkins press, Baltimore, p 85

Roberts AP, Almeida TP, Church NS, Harrison RJ, Heslop D, Li Y, Muxworthy AR, Williams W, Zhao X (2017) Resolving the origin of pseudo-single domain magnetic behavior. J Geophys Res Solid Earth 122:9534-9558. https://doi.org/ 10.1002/2017JB014860

Roberts AP, Pike CR, Verosub KL (2000) First-order reversal curve diagrams: a new tool for characterizing the magnetic properties of natural samples. J Geophys Res 105:28461-28475. https://doi.org/10.1029/2000JB900326

Rochette P, Mathe P-E, Esteban L, Rakoto H, Bouchez J-L, Liu Q, Torrent J (2005) Non-saturation of the defect moment of goethite and fine-grained hematite up to 57 Teslas. Geophys Res Lett 32:L22309. https://doi.org/10.1029/2005GL024196

Rowan CJ, Roberts AP (2006) Magnetite dissolution, diachronous greigite formation, and secondary magnetizations from pyrite oxidation: unravelling complex magnetizations in Neogene marine sediments from New Zealand. Earth Planet Sci Lett 244:119-137. https://doi.org/10.1016/j.epsl.2005.10.017

Sakamoto T, Sakai A, Hata M, Unozawa A, Oka S, Hiroshima T, Komazawa T, Murata Y (1987) The geological map of Japan, scale 1:200000, Tokyo. In: Geol Surv Japan, Tsukuba

Salzmann U, Williams M, Haywood AM, Johnson ALA, Kender S, Zalasiewicz JA (2011) Climate and environment of a Pliocene warm world. Palaeogeogr Palaeoclimatol Palaeoecol 309:1-8. https://doi.org/10.1016/.palaeo.2011.05.044

Satoguchi Y, Higuchi Y, Kurokawa K (2005) Correlation of the Ohta tephra bed in the Tokai group with a tephra bed in the Miura group, Central Japan. J Geol Soc J.jn 111:74-86 (in Japanese with English abstract)

Satoguchi Y, Nagahashi Y (2012) Tephrostratigraphy of the Pliocene to Middle Pleistocene series in Honshu and Kyushu Islands, Japan. Island Arc 21:149169. https://doi.org/10.1111/j.1440-1738.2012.00816.x

Sawada T, Shinoda R, Motoyama I, Kameo K (2009) Geology and radiolarian biostratigraphy of the Miocene and Pliocene series exposed along the Koitogawa River, Boso Peninsula, Japan. J Geol Soc Jpn 115:206-222 (in Japanese with English abstract)

Seki O, Foster GL, Schmidt DN, Mackensen A, Kawamura K, Pancost RD (2010) Alkenone and boron-based Pliocene $\mathrm{pCO}_{2}$ records. Earth Planet Sci Lett 292: 201-211. https://doi.org/10.1016/j.epsl.2010.01.037

Suzuki Y, Kodama K, Mitsunashi T, Oka S, Urabe A, Endo T, Horiguchi M, Eto T, Kikuchi T, Yamauchi S, Nakajima T, Tokuhashi S, Nirei H, Hara Y, Nakayama T, Nasu N, Kagami H, Kimura M, Honza E (1995) Geology of the Tokyo Bay and Adjacent Areas. Scale 1:100 000. In: Geol Surv Japan, Tsukuba

Tada R, Irino T, Ikehara K, Karasuda A, Sugisaki S, Xuan C, Sagawa T, Itaki T, Kubota Y, Lu S, Seki A, Murray RW, Alvarez-Zarikian C, Anderson WT Jr, Bassetti M-A, Brace BJ, Clemens SC, da Costa Gurgel MH, Dickens GR, Dunlea AG, Gallagher SJ, Giosan L, Henderson ACG, Holbourn AE, Kinsley CW, Lee GS, Lee KE, Lofi J, Lopes CICD, Pellitero MS et al (2018) High-resolution and -precision correlation of dark and light layers in the Quaternary hemipelagic sediments of the Japan Sea recovered during IODP Expedition 346. Prog Earth Planet Sci 5:19. https://doi.org/10.1186/s40645-018-0167-8 
Takeuchi K, Oikawa T, Saito M, Ishizuka O, Sanematsu K, Komazawa M (2015) The geological map of Japan, scale 1:200000, Yokosuka. In: Geol Surv Japan, Tsukuba, 2nd edn

Tamura I, Yamazaki H (2010) Significance of the remarkable unconformity in the Plio-Pleistocene of the Japanese Islands. Quat Int 219:45-54. https://doi.org/ 10.1016/j.quaint.2010.01.013

Tamura I, Yamazaki H, Mizuno K (2005) The Sakai volcanic ash and its correlatives: a 4.1-Ma (Early Pliocene) widespread tephra in Japan. J Geol Soc Jpn 111: 727-736 (in Japanese with English abstract)

Tamura I, Yamazaki H, Mizuno K (2008) Characteristics for the recognition of Pliocene and early Pleistocene marker tephras in central Japan. Quat Int 178: 85-99. https://doi.org/10.1016/j.quaint.2007.04.002

Tatsumi Y, Tamura Y, Nichols ARL, Ishizuka O, Takeshita N, Tani K (2016) Izu-Bonin Arc. In: Moreno T, Wallis S, Kojima T, Gibbons W (eds) The geology of Japan. Geological Society, London

Till JL, Guyodo Y, Lagroix F, Morin G, Menguy N, Ona-Nguema G (2017) Presumed magnetic biosignatures observed in magnetite derived from abiotic reductive alteration of nanogoethite. C R Geoscience 349:63-70 https://doi.org/10.1016/j.crte.2017.02.001

Till JL, Guyodo Y, Lagroix F, Morin G, Ona-Nguema G (2015) Goethite as a potential source of magnetic nanoparticles in sediments. Geology 43:75-78. https://doi.org/10.1130/G36186.1

Tokuhashi S (1988) Extent and form of individual turbidite sandstone beds in ancient submarine fan sediments. Sekiyu Gakkaishi 31:12-29 (in Japanese with English abstract)

Tokuhashi S, Danhara T, Iwano H (2000) Fission track ages of eight tuffs in the upper part of the Awa Group, Boso Peninsula, central Japan. J Geol Soc Jpn 106:560-573 (in Japanese with English abstract)

Tokuhashi S, Iwawaki T (1975) Areal sedimentary analysis of flysch-type alternations. Earth Sci (Chikyu Kagaku) 29:626-274 (in Japanese with English abstract)

Ueki T, Niwa M, Yonaga Y, Iwano H, Danhara T (2018) Zircon U-Pb dating and Fission track age of a Pliocene Ohta Tephra in the Tokai Group. In: Abstract SGL30-P02 presented at the JpGU Meeting 2018, Makuhari, Japan, 19-24 May 2018 https://confit.atlas.jp/guide/event/jpgu2018/subject/E_SGL30-P02/ tables?cryptold. Accessed 16 Oct 2018

Unozawa A, Oka S, Sakamoto T (1983) The geological map of Japan, scale, 1: 200000, Chiba. In: Geoll Surv Japan, Tsukuba

Utsunomiya M, Kusu C, Majima R, Tanaka Y, Okada M (2017) Chronostratigraphy of the PlioceneePleistocene boundary in forearc basin fill on the Pacific side of central Japan: constraints on the spatial distribution of an unconformity resulting from a widespread tectonic event. Quat Int 456:125-137. https:// doi.org/10.1016/j.quaint.2017.05.034

Valet JP, Fournier A (2016) Deciphering records of geomagnetic reversals. Rev Geophys 54:410-446. https://doi.org/10.1002/2015RG000506

Valet JP, Meynadier L, Guyodo Y (2005) Geomagnetic dipole strength and reversal rate over the past two million years. Nature 435:802-805. https://doi. org/10.1038/nature03674

Verwey EJW (1939) Electronic conduction of magnetite (Fe3O4) and its transition point at low temperatures. Nature 144:327-328. https://doi.org/10.1038/ 144327b0

Watanabe M, Takahashi M (2000) Diatom biostratigraphy of the middle Miocene marine sequence of the Kawadani section in the Kamogawa are, Boso Peninsula, central Japan. J Geol Soc Jpn 106:489-500 (in Japanese with English abstract)

Yamamoto Y, Kawakami S (2005) Rapid tectonics of the Late Miocene Boso accretionary prism related to the Izu-Bonin arc collision. Island Arc 14:178-198. https://doi.org/10.1111/j.1440-1738.2005.00463.x

Yoshida S, Shibuya H, Torii M, Sajima S (1984) Post-Miocene clockwise rotation of the Miura Peninsula and its adjacent area. J Geomagn Geoelectr 36:579-584. https://doi.org/10.5636/jgg.36.579

Zijderveld JDA (1967) Demagnetization of rocks: analysis of results. In: Collison DW, Creer KM, Runcorn SK (eds) Method in Palaeonmagnetism. Elsevier, Amsterdam

\section{Submit your manuscript to a SpringerOpen ${ }^{\circ}$ journal and benefit from:}

- Convenient online submission

- Rigorous peer review

- Open access: articles freely available online

- High visibility within the field

- Retaining the copyright to your article

Submit your next manuscript at $\boldsymbol{\nabla}$ springeropen.com 